\title{
PHANEROZOIC BRITTLE TECTONICS IN THE SOUTH AMERICAN CONTINENTAL PLATFORM, SOUTHEAST BRAZIL: NEW INSIGHTS FROM FISSION TRACK STUDIES ON APATITE IN REACTIVATED FAULT ZONES
}

\section{LUIZ FELIPE BRANDINI RIBEIRO ${ }^{1}$, CARLOS ALBERTO TELLO SAENZ ${ }^{2}$, PEDRO JOSÉ IUNES ${ }^{2}$, PETER CHRISTIAN HACKSPACHER ${ }^{1}$, JULIO CESAR HADLER NETO ${ }^{2}$ \& SERGIO R. PAULO ${ }^{3}$}

\begin{abstract}
Apatite Fission Track Method (FTM) studies were performed on samples coming from two different fault domains in the Precambrian basement of southeast Brazil in order to evaluate subsequent Phanerozoic tectonic movements in that part of the South American Platform. The samples studied were collected along brittle faults in the Mantiqueira mountain range and in the Jundiai upland plain (Bragança Paulista and Extrema), approximately $100 \mathrm{~km}$ northeast of São Paulo, Brazil. The results of paleostress analysis, as well as the presence of as pseudotachylyte material in the reactivated fault zones, indicates a rapid strain rate and high frictional temperature along these faults.

The recognition of deformation related to this brittle tectonic regime is of key importance for the reconstruction of Paleozoic and Mesozoic tectonic evolution of the South American Platform. The causal effects of these tectonic readjustments of cratonic rocks during the breakup of West-Gondwana during the Cretaceous and also in younger geological history, are some of the key parameters for understanding thePhanerozoic evolution of the Mantiqueira mountain range.

Our FTM data shows the oldest regional thermal histories are recorded in the Jundiaí upland plain beginning in the Upper Triassic $(\sim 190 \mathrm{Ma})$ at $50^{\circ} \mathrm{C}$, indicating a rapid cooling that is coincident with the tectonic subsidence of the Paraná Basin and, probably, the uplift and preservation of Gondwana surface. These data also show slow linear heating (between 50 to $90^{\circ} \mathrm{C}$ ) of the southeastern Brazilian margin up to the Lower Cretaceous ( 120 Ma). This phenomenon could either be related to migration of the Trindade plume, or extensional/compressional movements. At $\sim 120 \mathrm{Ma}$ a structural inversion occurred and the previous slow linear heating was replaced by slow linear cooling (from 90 to $25^{\circ} \mathrm{C}$ ) that has persisted up to the present time.

Locally, in the younger fault domain, in the Mantiqueira Range near Extrema, fission tracks began to be recorded at $\sim 110 \mathrm{Ma}$ ago and were, since then, submitted to a slow linear cooling very similar to that observed for two country rock samples and the samples collected in the older faulted rocks (Bragança Paulista). Then considering the thermal histories of all the samples studied here, there is an agreement about a pervasive thermal event taking place $\sim 110 \mathrm{Ma}$ ago followed by a linear cooling up to the present, related to regional erosion. These processes are considered to be related to the South-Atlantic opening, with widespread extensional tectonic movements along the southeastern Brazilian coast.
\end{abstract}

Keywords: Fission Track Method on Apatite, fault reactivation, Thermal Histories, Thermotectonic Evolution

\begin{abstract}
INTRODUCTION The Phanerozoic evolution of the South American Platform has a complex and poorly known history that involved reactivation of Precambrian basement structures. These reactivations generated significant pulses of uplift and subsidence, followed subsequent and erosional and depositional events. Following Brasiliano orogenesis, the southeastern part of the South American platform remained tectonically quiescent until the Cambro-Ordovician period. A phase of crustal thickening (underplating) occurred during the Permian possibly due to disturbances considered be caused by heating and thinning of the continental lithosphere. During the Upper Triassic a pulse of subsidence affected the Paraná Basin (Françolin 1996), which was simultaneous with reactivation and uplift in the Mantiqueira mountain range. This resurgent tectonic phase occurred due to intraplate stresses that generated seismicity and sudden uplifts in the Triassic, as shown by the beginning uplift of the Ponta Grossa Arch and uplift of sediments of the Itararé Formation (Macedo et $a l, 1991)$. Between the Cretaceous and Miocene (140 - $20 \mathrm{Ma})$, other intraplate tectonic movements occurred in response to the opening of the Atlantic Ocean and related hot spot plume
\end{abstract}

development. This reactivation is known as the Wealdeniana Reactivation (Almeida, 1967) or Sul-Atlantiana (Schobbenhaus et al. 1981). During the Cretaceous, alkaline, ultrapotassic and ultramafic intrusions crosscut the São Francisco Craton, in the region of Catalão I and II, Poços de Caldas and Cabo Frio Magmatic Alignment (Gibson et al. 1995). This period was also marked by extrusion of basic magmas on the Paraná Basin as well as extensive faulting and a strong widespread extensional tectonic along the southeastern Brazilian coast. Pigeon (1985) and Lima et al. (1999) related the epiorogenic uplifting of vast continental areas to an isostatic response to lithospheric thickening, resulting from the intrusion of great amounts of mafic magma, in the lower part of the crust. These magmas were also extruded as evidenced by the flood basalts of the Parana - Etendeka Province. Cox (1989) correlated crustal thickening observed in Namibia,Angola, in Africa, with southeastern Brazilian evolution. McKenzie (1984) and Cox (1989) associated this underplating to a hot spot plume. Two models have been proposed to explain the Cretaceous mantle plume intrusion:

1) that asymmetry of the magmatism and present day

1 - Instituto de Geociências e Ciências Exatas, Universidade Estadual Paulista, 13506-900, Rio Claro, SP, Brasil. E-mail: 1fbrv@yahoo.com.br

2 - Instituto de Física "Gleb Wataghin”, Universidade Estadual de Campinas, 13083-970, Campinas, SP, Brasil.

3 - Departamento de Física, Instituto de Ciências Exatas e da Terra, Universidade Federal de Mato Grosso, 78060-900, Cuiabá, MT, Brasil. 
topography may be due to the migration of plume into the southeastern Brazil (Gallagher \& Hawkesworth 1994), or 2) that the plume from lower mantle to upper one through narrow conduit emerging around the border of the Paraná Basin (VanDecar et al. 1995). The Serra do Mar and Mantiqueira mountain ranges record extensive faulting and a strong tectonic a movements at that time (Asmus \& Ferrari, 1978, Guedes et al, 2000), related to extrusion of basic magmas in the Parana Basin. Two models were proposed to explain the uplift of the Mantiqueira and Serra do Mar mountain ranges and the subsidence of the Atlantic Ocean platform: 1) an extensional one (Fernandes 1993), where uplift process elevated the mountain ranges and was compensated by the subsidence of the Atlantic Ocean platform and Taubaté Basin; and 2) a compressional one, resulting from a main NW sub-horizontal compression with uplift related to the plate motion and Andean compression (Ribeiro 1996, Lima et al. 1997).

Under this latter proposal the main stress controlled all the fault directions. The fault material formed during these processes shows structural and petrologic characteristics that give indications about the amount of pressure and temperature dynamic conditions (Ribeiro et al. 1999).

The objective of our investigation was to use the Fission Track Method (FTM) on apatite, relating ages and thermal histories to study Phanerozoic brittle tectonic activity. Our assumption was that method was valid if heating produced by fault (or its reactivation) produces total or partial track annealing and the subsequent thermal history are registered by the fission tracks. For this investigation, we separated apatite grains from granitic rocks of the Socorro Complex, near the Extrema Fault (Figs.1 and 2) from rocks in the southern part of the Mantiqueira mountain range, northwest São Paulo, Brazil. The granites represent pre-colisional magmatism with U/Pb age of $650 \mathrm{Ma}$ (Ebert et al. 1996) affected by later collisional and pos-collisional tectonic readjustments and followed by cooling at $569 \pm 18 \mathrm{Ma}\left({ }^{39} \mathrm{Ar} /{ }^{40} \mathrm{Ar}\right.$, Ribeiro 2003). The samples were collected in profiles both close to $(\sim 10 \mathrm{~cm})$ and far from $(\sim 2 \mathrm{Km})$ small brittle faults, containing cataclasites, fault gouges and fault breccias.

GEOLOGIC SETTING The study area is located in the central part of southeast Brazil's in Mantiqueira Province (Cordani et al. 2000) a collage of Archean, Paleoproterozoic and Neoproterozoic rocks that were strongly deformed and metamorphosed during Brasiliano/Pan African orogenesis. Towards the end of the Brazilian Orogeny, around $600 \mathrm{Ma}, \mathrm{NE} / \mathrm{SW}$ strike-slip shear zones affected the region, forming the Extrema Shear Zone. Distinct lithological domains of metasediments and migmatites of the Amparo and Itapira complexes and granitic rocks of the Socorro Complex are described (Wernick 1978, Artur 1980) (Fig. 2). The migmatitic Amparo Complex (Hasui \& Oliveira 1984) records both Paleoproterozoic and Neoproterozoic metamorphism (Artur 1988, Tassinari and Nutman, 2001) and yields an Archean protolith age (Fetter et al. 2001). The Itapira Complex of Paleo- to Mesoproterozoic sedimentation is composed of paragneisses and migmatite. The Neoproterozoic Socorro Complex is characterized by quartzmonzodiorites of the Bragança suite and biotite granite of the Salmão Suite (Fig. 2).

During the Phanerozoic, brittle tectonic movements reactivated some of the older crustal structures in SE Brazil that developed during the Brasiliano Orogeny. These younger tectonic movements frequently formed structures of pull-apart basins, drainage systems, or other morphologic assemblages. During the Cambro-Ordovician period, NW-SE aulacogenic graben structures affected the Precambrian basement, producing conditions for the initial sedimentation of the Parana Basin. This tectonic event was also recorded in the basement through faulting and thermal events. The Extrema Fault system is a result of the Phanerozoic reactivation of the Extrema Shear Zone. This reactivation was responsible to formation the fault rocks, related to thermal episodes, which produced total annealing of the spontaneous fission tracks present in minerals such as apatite. Miocene and Pleistocene sediments
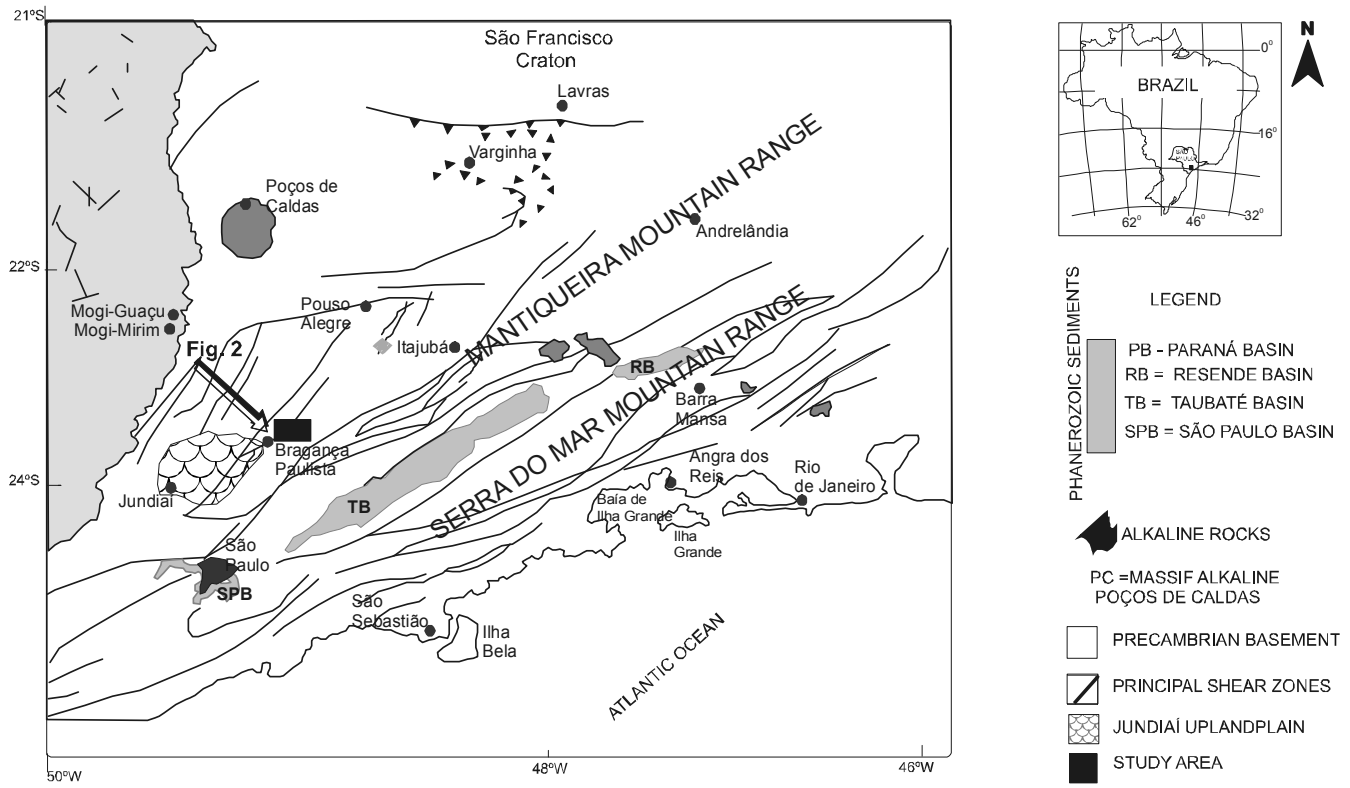

Figure 1 - Simplified geologic Map showing Southeastern Brazilian basement with the main Neoproterozoic shear zones, Phanerozoic sediments and studied area (g)(modified after Schobbenhaus et al., 1981). 
are restricted to small areas. Tertiary and Quaternary fluvial sediments can be found along the Atibaia, Jaguari rivers (Fulfaro et al, 1985, Bistrichi 2001).

FISSIONTRACKMETHOD ONAPATITE TheFTM onapatite (Price \& Walker 1963) is based on spontaneous fission of U-238, the most abundant isotope of uranium. Over geological time, detectable amounts of spontaneous fission tracks can accumulate in those minerals. When a U-238 spontaneous fission occurs two highly charged fission fragments liberate approximately $170 \mathrm{Mev}$ of energy inside the mineral structure, ionizing and dislocating the atoms found near the trajectories of both fragments. These atoms, being ionized, repeal each other creating a region called "latent track": a cylindrical zone free of atoms (50 to 100 Angstroms in diameter and around $20 \mu \mathrm{m}$ in length) surrounded by a region where the crystalline structure is disrupted (see, for instance, Wagner \& Van den Haute 1992). If the mineral is properly etched, as the latent tracks are more reactive than the rest of premineral, they are amplified so that they can be observed by optical microscopy. The fission track age of the mineral (or the age of the last thermal event that annealed all the spontaneous tracks produced previously) can be obtained by counting these spontaneous fission tracks on a suitably polished surface of the mineral and having knowledge of its uranium concentration, $\mathrm{N}_{\mathrm{u}}$. In practice, to avoid the $\mathrm{N}_{\mathrm{u}}$ measurement, a fraction of the mineral, which was previously heated in laboratory to erase totally its spontaneous tracks, is irradiated with thermal neutrons, inducing fission in U-235, a isotope whose abundance ratio with the U-238,
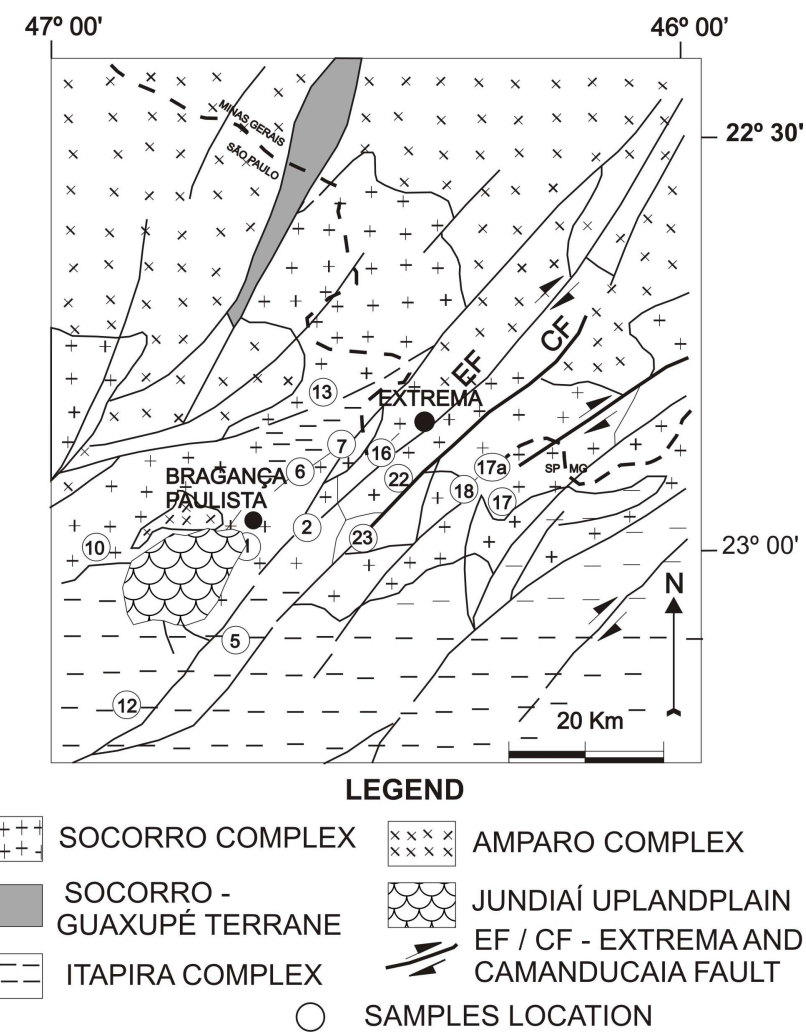

Figure 2- Simplified geological map showing the sample locations (modified after Schobbenhaus et al., 1981 and Ebert et al. 1996) $\mathrm{h}$, is constant in nature (and the minerals). By counting induced and spontaneous fission track densities, $\rho_{\mathrm{I}}$ and $\rho_{\mathrm{S}}$, respectively, in the samples that were previously polished and etched, one can obtain the age of the mineral (Price \& Walker 1963):

$$
T=\frac{1}{\lambda} \ln \left(1+\frac{\lambda \sigma_{0} \phi_{0}}{\lambda_{f} \eta}\left(\frac{\rho_{S}}{\rho_{I}}\right)\right) \ldots \ldots \ldots . . .(1)
$$

Where $\lambda$ is the U-238 alpha decay constant, $\sigma_{0}$ is the average cross section for the U-235(n,fission) reaction, $\phi_{0}$ is the flux of thermal neutrons and $\lambda_{f}$ is the U-238 decay constant by spontaneous fission. It is well known that the length of latent tracks is sensitive to temperature. Thermal treatments carried out in laboratory (for example, Green et al. 1986, Crowley et al. 1991, Carlson et al. 2000, Tello et al. 2002) and even storage at room temperature over geological time (Bigazzi, 1967, Wagner 1968) can produce significant track length shortening. In this case, there is a lower probability of crossing the observation surface, compared with the one of tracks originated from fresh fission events. Due to this, equation 1 should be generally taken as the apparent mineral age, $T_{a p}$, which can be younger than its stratigraphic age (rock age). $T_{a p}$ ap depends on the parameters: $\lambda, \sigma_{0}, \phi_{0}, \lambda l_{\mathrm{f}}$ and $\eta$. The value of the constant $\lambda_{\mathrm{f}}$ is the one that has been mostly debated; it has been measured many times and the experimental results are grouped around two values that differ by $\sim 20 \%$. Looking at equation 1 one can see that another possible source of this systematic error is related with the parameters of the neutron irradiation, i. e. the product $\phi_{0} \sigma_{0}$ (Wagner \& Van den Haute 1992). The use of those parameters can be avoided by irradiating together the samples along with a sample of a standard mineral (e.g. the Durango apatite) whose age is well known.

The age of this standard mineral, $\mathrm{T}_{\mathrm{STD}}$, is given by:

$$
T_{S T D}=\frac{1}{\lambda} \ln \left(1+\frac{\lambda \sigma_{0} \phi_{0}}{\lambda_{f} \eta}\left(\frac{\rho_{S(C O R R)}}{\rho_{I(C O R R)}}\right)_{S T D}\right) \ldots \ldots \ldots . . .(2)
$$

where $\mathrm{r}_{\mathrm{S}(\mathrm{CORR})}=\rho_{\mathrm{S}} / \mathrm{c}$, where the correction factor $\mathrm{c}$ is the correction of the spontaneous track density, which takes properly into account the annealing suffered by the standard mineral during its geological history (see appendix 1); $\rho_{\mathrm{I}(\mathrm{CORR})}$ is the correction of induced fission track originated by ratio thorium $(\mathrm{Th})$ /uranium $(\mathrm{U})$ of the standard sample.

The standard sample utilized in this work was the Durango apatite, which has a relatively high ratio $\mathrm{Th} / \mathrm{U} \sim 30$ that is the case of minerals such as pegmatite (Parent rocks). Then the Th can also contribute with induced fission tracks when the reactor neutron spectrum is not well thermalized, that is the case of the reactor of IPEN, SP, Brazil, where the samples were irradiated. In this work we estimated this effect as in Iunes et al. (2002). On the other hand, the samples such as granitic rocks, the samples analyzed here, have a ratio $\mathrm{Th} / \mathrm{U} \sim 2$ making negligible the contribution of induced fission tracks of Th. Eliminating $\left\{\left(\lambda \sigma_{0} \phi_{0} /\left(\lambda_{\mathrm{f}} \eta\right)\right\}\right.$ that is found both in equation 1 and 2 , the apparent age of the sample whose age is unknown is:

$$
T_{A P}=\frac{1}{\lambda} \ln \left\{1+\left[\left[\operatorname{EXP}\left(\lambda T_{S T D}\right)-1\right] \frac{\left(\frac{\rho_{s}}{\rho_{I}}\right)_{U N K}}{\left(\frac{\rho_{S(C O R R)}}{\rho_{I}}\right)_{S T D}}\right]\right\} \ldots \ldots \ldots \ldots \ldots . . .(3)
$$

Where $\left(\rho_{\mathrm{S}} / \rho_{\mathrm{I}}\right)_{\mathrm{UNK}}$ corresponds to the unknown age sample. The corrected age, $\mathrm{T}_{\text {CORR }}$, is obtained from equation 3 by applying the "size correction" method (Storzer \& Wagner, 1969) by which $r_{s}$ of the unknown age sample, $\left(\rho_{\mathrm{S}}\right)_{\mathrm{UNK}}$, is substituted by its correction, $\mathrm{r}_{\mathrm{S}(\mathrm{CORR})}(\mathrm{see}$, also, appendix 1$)$. 
The mechanisms by which thermal activity progressively erase latent tracks formed in the crystallographic structure of apatite are not completely known, but experimental observations (Green et al. 1986, Crowley et al. 1991, Carlson et al. 2000, Tello et al. 2002a) have shown that the net effect of annealing is the reduction of track lengths. Then, as spontaneous fission tracks are produced continuously during the geological history in Apatite, by studying their length distribution one can obtain information about the thermal history of the analyzed apatite sample. A track length distribution is obtained by measuring only the "horizontal confined tracks" (tracks totally contained inside the apatite bulk that are parallel to the observation surface). These kinds of tracks are developed if they are located very close to crystallographic defects or other tracks reaching the apatite surface, so that the penetration of the chemical etchant into them is possible.

EXPERIMENTALPROCEDURE The apatite samples studied in this work were obtained in grains of $\sim 200 \mu \mathrm{m}$ in diameter. A piece of the apatite used as standard, the Durango one, was crushed into pieces of approximately the same size, since all the samples analysed here were treated under the population method (Gleadow et al., 1981). A fraction of each sample was heated at $450^{\circ} \mathrm{C}$ for 10 $\mathrm{h}$ to erase completely the spontaneous tracks. Then these fractions were irradiated in the IPEN/CNEN nuclear reactor with a thermal neutron nominal flux of $1 \times 10^{15}$ neutrons per $\mathrm{cm}^{2}$ (Dr. Marília Tereza Freitas, personal communication).

Following irradiation, grains belonging both to the irradiated and non-irradiated fractions were mounted in different assemblies of epoxy resin and polished with diamond paste. Later, both assemblies were chemically etched simultaneously with a $5 \% \mathrm{HNO}_{3}$ solution for $50 \mathrm{~s}$ at $20^{\circ} \mathrm{C}$ and were then observed under a Leitz/ Wetzlar Dialux 20EB optical microscope, at a 12.5 x 100 (oil) nominal magnification. Induced and spontaneous fission track countings were done using a square calibrated reticulate properly adapted inside the microscope ocular, which defined the observation field under the observation conditions mentioned above. For each sample, these measurements were carried out by counting the tracks found only in the first observation field randomly chosen in each apatite grain. Confined track length measurements were performed using a calibrated ruler (precision of $0.53 \mu \mathrm{m}$ ) coupled to the microscope ocular.

For this procedure the samples were separated in two groups, both submitted to the same conditions concerning nominal neutron flux and irradiation facility, but irradiated at different times. In the group irradiated first, the Durango apatite was used as standard sample, placed in the center of the irradiation assembly. Pieces of another apatite sample, the TA-1, were placed at the edges of the assembly and coupled to the Durango to determine whether a correction factor due to neutron flux gradient should be considered. The samples contained in this assembly (first irradiation) were placed in following order: TA-1, LF-1, LF-5, LF-16, LF-17, TA-1, Durango, LF-17A, LF-18, LF-22, LF-23, TA-1 (where the first mentioned TA-1 sample defines the edge 1 of the assembly and the latter the edge 2). The induced track counting observed in the three TA-1 samples ( $\rho_{\mathrm{I}}\left(\right.$ ext-1), coupled to LF-1, $\rho_{\mathrm{I}}($ ext-2), coupled to LF-23 and $\rho_{\mathrm{I}}$ (center), coupled to Durango) are: $\rho_{\mathrm{I}}$ (ext-1) $=(1.54$ $\pm 0.10) \times 10^{5} \mathrm{~cm}^{-2}, \rho r_{\mathrm{I}}($ center $)=(1.423 \pm 0.073) \times 10^{5} \mathrm{~cm}^{-2}, \rho_{\mathrm{I}}(\mathrm{ext}-2)=$ $(1.52 \pm 0.10) \times 10^{5} \mathrm{~cm}^{-2}$. These $r_{\mathrm{I}}$ are statistically compatible with a constant value, i.e. there was no neutron gradient during this irradiation, where $\rho_{\mathrm{I}}(\mathrm{std})=(2.67 \pm 0.08) \times 10^{5} \mathrm{~cm}^{-2}$ was obtained for the Durango apatite. For the group of samples irradiated later (second irradiation), other three pieces of TA-1 were again placed at the same location inside the assembly, as in the first irradiation. As such, they could be utilized both to correct a possible flux gradient as to calibrate the second irradiation against the first one, making the presence of Durango apatite in the second irradiation unnecessary. The samples contained in the assembly of the second irradiation were placed in following order: TA-1, LF-2, LF-6, LF-7, TA-1, LF-10, LF-12, LF-13, TA-1. The $\rho_{\mathrm{I}}$ values of the TA-1 samples found in the second irradiation were: $\rho_{\mathrm{I}}($ ext-1 $)=(1.656 \pm 0.087) \times 10^{5}$ $\mathrm{cm}^{-2}, \rho_{\mathrm{I}}$ (center $)=(1.795 \pm 0.085) \times 10^{5}$ and $\rho r_{\mathrm{I}}($ ext-2 $)=(1.75 \pm 0.14) \times 10^{5}$ $\mathrm{cm}^{-2}, \mathrm{i}$. e. also in this case there was no neutron gradient.

RESULTS Table 1 (first irradiation), and Table 2 (second irradiation) show the results obtained in the experimental measurements. The $n_{S}$ and $n_{I}$ values are the numbers of grains where track counting was performed at the microscope, resulting in a total number of spontaneous and induced counted tracks, $\mathrm{N}_{\mathrm{S}}$ and $\mathrm{N}_{\mathrm{r}}$. The $\mathrm{n}_{\mathrm{CS}}$ and $\mathrm{n}_{\mathrm{CI}}$ are the number of confined spontaneous and induced tracks whose lengths $\mathrm{L}_{\mathrm{S}}\left(\mathrm{L}_{\mathrm{I}}\right)$ were measured. The value of the average length of the unannealed confined induced tracks $\left(\mathrm{L}_{0}\right)$ was obtained through the weighted average among the average values of the samples LF-5, LF-17, LF-7, LF10 e LF-12, giving $\mathrm{L} 0=(16.05 \pm 0.04) \mathrm{mm}$. The spontaneous (induced) track counting, in $\mathrm{cm}^{-2}$, is $\rho_{\mathrm{S}}\left(\rho_{\mathrm{I}}\right)$. In the case of Durango sample, $\rho_{\mathrm{I}}$ (in Table 1 ) is the value corrected considering the contribution of induced fission tracks of $\mathrm{Th}$. The factor $\mathrm{C}$ for spontaneous track correction is also shown. The values of the constants appearing in equation 3 are:

i) Decay constant of U-238, $1=1.55 \times 10^{-10} \mathrm{a}^{-1}$ (Jaffey et al., 1971),

ii) age of the standard mineral (Durango apatite), $\mathrm{T}_{\mathrm{STD}}=(31.4 \pm$ 0.5) $\times 10^{6}$ a. (Hurford., 1990),

iii) for the first irradiation,

$$
\left[\frac{\rho_{S}(\text { corr })}{\rho_{I}}\right]_{S T D}=(0.6496 \pm 0.0741)
$$

was obtained and for the second irradiation, where the induced counting performed using TA-1 samples substituted the value one would obtain if Durango apatite was present,

$$
\left[\frac{\rho_{S}(\text { corr })}{\rho_{I}}\right]_{S T D}=(0.5150 \pm 0.0689)
$$

was obtained. The age errors were calculated by propagation, always considering the greatest value between the experimental and Poissonian standard deviations, concerning the data of each sample.

ANALYSIS OF THE AGES Using the data of Tables 1 and 2 , the apparent $\left(\mathrm{T}_{\mathrm{ap}}\right)$ and corrected $\left(\mathrm{T}_{\text {corr }}\right)$ ages were obtained. They are shown in Table 3, where the samples were classified in three groups representing different geological settings: i) outside the faults (LF10 and LF-13), i. e. samples collected far ( $2 \mathrm{Km})$ from the faults; ii) older fault in Bragança Paulista region located about $50 \mathrm{Km}$ of Extrema region (LF-1, LF-2, LF-5, LF-6 and LF-7). These samples were collected in faults where the presence of pseudotachylytes was frequent and blue quartz rare. In these samples, paleostress measurements performed "in situ" showed NE sub-horizontal compressive stresses and NW sub-horizontal tensile stresses. This indicates that the faults took place due to reactivations of transtensional nature presenting a normal and transcurrent components; iii) younger fault in Extrema region (LF-12, LF-16, LF17, LF-17A, LF-18, LF-22 and LF-23). These samples were collected 
in faults where blue quartz, breccias and cataclasites were usually found. In these cases, "in situ" paleostress measurements showed NW sub-horizontal compressive stresses and NE sub-horizontal tensile stresses indicating a compression regime made up by dextral and sinistral transcurrent faults.

In Table 3 both the apparent $\left(T_{a p}\right)$ and corrected $\left(T_{c o r}\right)$ mean ages are presented, for each group in which the samples were divided. According to the result of the $\chi^{2}$ test, shown in Table 3 , the apparent ages of the samples collected both near the older fault (Bragança Paulista region) and far $(\sim 2 \mathrm{Km})$ from the fault systems present internal consistency $\left(\mathrm{P}\left(\chi^{2}\right)\right.$ obtained is inside the confidence interval, i.e. $\left.0.05<\mathrm{P}\left(\chi_{\mathrm{v}}^{2}\right)<0.95\right)$, while the samples belonging to the younger fault (Extrema region) present ages whose consistency is found to be outside of that interval. Then one can't state that all the samples of this latter group actually belong to it. Looking at Table 3, one sees that LF-18 sample is probably the cause of this incongruity in the younger fault, which will be discussed below. Analyzing ( $\left.T_{a p}\right)$ (and their errors) both for the samples found far from the faults as near the older fault one observes that they can not be considered different, if $\chi^{2}$ acceptance is taken into account. The analysis of a greater amount of samples collected far from the fault systems give more support to this result; this is being performed in another work that is in course. Otherwise, $\left(T_{a b}\right)$ of the samples found in the younger fault are statistically lower than the ones belonging both to the older fault and outside the fault, confirming the paleostress analysis of Extrema fault zone discussed in Ribeiro (1996).

The corrected ages obtained in this work were utilized only to construct the time interval $\left(t_{\text {corr }}+2 \sigma_{\text {tcorr }}\right)$ connected with the first attempt to rebuild the thermal histories of the samples $\left(1^{\text {st }}\right.$ Monte Carlo box) as it is shown in the following.

THERMAL HISTORIES In this work, the Monte Carlo method (see, for instance, Shreider 1966) was employed with an annealing model (Laslett et al. 1987) to create random thermal histories, which generate theoretical track length histograms that are then compared with the correspondent experimental histograms (Tello 1994, Hadler et al. 1995, Tello et al. 2002b). Thermal histories were obtained using "Monte Carlo Boxes", which are suitable areas in a temperature versus time diagram. A thermal history is generated by choosing, via Monte Carlo method, a point inside each one of the boxes and then neighboring points are connected by straightline segments. The point chosen in the last box is linked to a fixed point $\left(\mathrm{t}=0\right.$ and $\left.\mathrm{T}=25^{\circ} \mathrm{C}\right)$, representing the present day conditions. Then this group of straight line segments constitutes a possible thermal history generating a value of apparent age and a length histogram that are statistically compared with the experimental results. This thermal history will be accepted if it fulfills two conditions: 1) the calculated apparent age value lies between two standard deviations around the experimental value, and 2) the calculated and experimental histograms are compatible under the $\chi^{2}$ test (Lutz \& Omar 1991). In this work, the boxes were defined starting from some conditions, i.e. the corrected mean age obtained by FTM and the following geological data: the geothermal gradient for Bragança Paulista region as $22.8 \pm 2.3^{\circ} \mathrm{C} / \mathrm{Km}$ (Hamza et al. 1989 ), where an error of $10 \%$ was assumed, the crystallisation depth of 8-11 Km (personal communication of Prof Dr. Antônio Carlos Artur, UNESP, Rio Claro, SP, Brazil) during the formation of the granitic rock and the granite age of $650 \mathrm{Ma}$ (Ebert et al. 1996, Hackspacher et al. 2003). For the three groups in which the samples were classified, the criterion of employing the same Monte Carlo boxes to the samples belonging to a same group was observed. For each group, the time interval of the Monte Carlo boxes is:

$$
\Delta t=t_{\text {corr }} \pm 2 \sigma_{\text {tcorr }}
$$

Where $t_{\text {corr }}$ is the weighted mean age calculated among the individual ages composing each group, $\sigma_{\text {tcoo }}$ is the highest value between the experimental standard deviation (without considering the error of each age) and the weighted mean standard deviation.

The temperature interval of the Monte Carlo boxes is:

maximum temperature: $\mathrm{T}_{\mathrm{MAX}}=\left(\mathrm{T}_{\mathrm{er} \mathrm{MAX}} \cdot \mathrm{GG}_{\mathrm{MAX}} \cdot \mathrm{t}_{\mathrm{MAX}}\right)+\mathrm{T}_{\text {sup }}$ minimum temperature: $\mathrm{T}_{\mathrm{MIN}}=\left(\mathrm{T}_{\text {er MIN }} \cdot \mathrm{GG}_{\mathrm{MIN}} \cdot \mathrm{t}_{\mathrm{MIN}}\right)+\mathrm{T}_{\text {sup }}$ where: $T_{\text {er MAX }}=0.0168 \mathrm{Km} / \mathrm{Ma}$ is the maximum erosion rate, defined as the highest depth divided by the granitic age, $\mathrm{T}_{\text {er MIN }}=0.0122$ $\mathrm{Km} / \mathrm{Ma}$ is the minimum erosion rate, defined by the minimum depth divided by the granite age.

The geothermal gradient (GG), maximum and minimum, are:

$$
\begin{aligned}
\mathrm{GG}_{\mathrm{MAX}} & =27.4^{\circ} \mathrm{C} / \mathrm{Km}(\mathrm{GG}+2 \sigma), \\
\mathrm{GG}_{\mathrm{MIN}} & =18.2^{\circ} \mathrm{C} / \mathrm{Km}(\mathrm{GG}-2 \sigma)
\end{aligned}
$$

And $\mathrm{t}_{\mathrm{MAX}}=\mathrm{t}_{\text {corr }}+2 \sigma_{\text {tcorr }}$ and $\mathrm{t}_{\mathrm{MIN}}=\mathrm{t}_{\text {corr }}-2 \sigma_{\text {tcorr }}$, are the maximum and minimum time of the first Monte Carlo box. And, finally $\mathrm{T}_{\text {sup }}=$ $25^{\circ} \mathrm{C}$ is the surface temperature. Figure 3 shows the histograms of the spontaneous confined tracks obtained experimentally. To find the thermal histories of each set of samples, two treatments were developed. The first considering the sample LF-18 that belongs to the group of the younger fault, and second, discarding that sample.

First Treatment In this treatment the three groups, in which the samples were previously classified, according their geological characteristics, were maintained. Using the procedure described above, the dimensions of the first box, in time and temperature, for each sample group, were determined. Each group was analyzed aiming that all samples belonging to it would accept at least one thermal history among the 500 randomly chosen in each run. In principle, it is expected that all samples of a same group, presenting common geological characteristics, should accept thermal histories generated from a same Monte Carlo box (or a same set of Monte Carlo boxes). The accepted thermal histories were used to guide the construction of a new and more restricted generation of Monte Carlo boxes, called in the text as $1^{\text {st }}$ restriction, $2^{\text {nd }}$ restriction, etc.

Samples outside the faults The results showed that no thermal histories were accepted in the first (Fig. 4a) and second restrictions (Fig. 4b), meaning that the geothermal gradient cannot be considered constant in the region where the correspondent samples were collected. Then, in the third restriction, time and temperature intervals were totally opened for both boxes (Fig. 4c), so that any possible thermal history could be tested. In doing this, one must stress that any geological data used previously to build the Monte Carlo boxes were ruled out.

The result of this procedure was that three thermal histories were accepted, among the 500 tested, by the sample LF-10. Guided by these accepted thermal histories a fourth restriction was imposed, generating the accepted thermal histories shown in figures $4 \mathrm{~d}$ and $4 \mathrm{e}$, for LF-10 and LF-13, respectively. Repeating this procedure, i. e. defining the next restriction (the fifth, in this case) based on the thermal histories accepted in the previous restriction, one can see more clearly the accepted thermal histories for both samples (Figs. 4f and 4g): a heating followed by a cooling, which occurred in the last $\sim 120$ Ma.

Old fault (Bragança Paulista region) As the mean corrected 
Phanerozoic brittle tectonics in the South American Continental Platform, southeast Brazil: new insights from Fission Track studies on apatite in reactivated fault zones

Table 1 - Fission-track data of the samples submitted to the first neutron irradiation.

\begin{tabular}{|c|c|c|c|c|c|c|c|c|c|c|c|c|c|c|c|}
\hline Sample & $\mathrm{n}_{\mathrm{Cs}}$ & $\begin{array}{c}\mathrm{L} \pm 1 \sigma \\
(\mu \mathrm{m})\end{array}$ & $\begin{array}{l}S_{L S} \\
(\mu \mathrm{m})\end{array}$ & $\mathrm{n}_{\mathrm{s}}$ & $\mathrm{N}_{\mathrm{s}}$ & $\begin{array}{c}\rho_{\mathrm{s}} \pm 1 \sigma \\
\left(\mathrm{x} 10^{5} \mathrm{~cm}^{-2}\right)\end{array}$ & $\mathrm{S}_{\rho \mathrm{s}}(\%)$ & $\mathrm{n}_{\mathrm{CI}}$ & $\begin{array}{c}\mathrm{L}_{\mathrm{I}} \pm 1 \sigma \\
(\mu \mathrm{m})\end{array}$ & $\begin{array}{c}\mathrm{S}_{\mathrm{LI}} \\
(\mu \mathrm{m})\end{array}$ & $\mathrm{n}_{\mathrm{I}}$ & $\mathrm{N}_{\mathrm{I}}$ & $\begin{array}{c}\rho_{\mathrm{I}} \pm 1 \sigma \\
\left(\mathrm{x} 10^{5} \mathrm{~cm}^{-2}\right)\end{array}$ & $\begin{array}{l}\mathrm{S}_{\rho \mathrm{I}} \\
(\%)\end{array}$ & $\mathrm{C} \pm 1 \sigma$ \\
\hline \multicolumn{16}{|l|}{$1^{\text {st }} \operatorname{Irrad}$} \\
\hline TA-1 ( $1^{\text {st }}$ ext $)$ & - & - & - & - & - & - & - & - & - & - & 100 & 719 & $1.54 \pm 0.10$ & 68 & - \\
\hline LF-1 & 100 & $10.99 \pm 0.20$ & 2.00 & 100 & 899 & $17.37 \pm 0.87$ & 50 & - & - & - & 100 & 849 & $7.29 \pm 0.62$ & 85 & $0.57 \pm 0.07$ \\
\hline LF-5 & 100 & $11.73 \pm 0.21$ & 2.09 & 100 & 1437 & $29.75 \pm 1.53$ & 52 & 100 & $16.04 \pm 0.09$ & 0.77 & 100 & 579 & $11.18 \pm 0.58$ & 52 & $0.66 \pm 0.08$ \\
\hline LF-16 & 100 & $11.62 \pm 0.17$ & 1.68 & 100 & 1080 & $20.86 \pm 0.87$ & 42 & - & - & - & 100 & 800 & $15.45 \pm 0.81$ & 53 & $0.66 \pm 0.08$ \\
\hline LF-17 & 100 & $12.10 \pm 0.17$ & 1.70 & 100 & 1215 & $5.87 \pm 0.36$ & 61 & - & - & - & 100 & 1042 & $5.03 \pm 0.35$ & 70 & $0.72 \pm 0.08$ \\
\hline TA-1 (center) & - & - & - & - & - & - & - & - & - & - & 100 & 686 & $1.423 \pm 0.073$ & 51 & $-(-)$ \\
\hline $\mathrm{LF}-17^{\mathrm{A}}$ & 100 & $11.45 \pm 0.17$ & 1.72 & 100 & 1072 & $20.71 \pm 0.83$ & 40 & 100 & $16.05 \pm 0.10$ & 1.0 & 100 & 1227 & $10.53 \pm 0.60$ & 57 & $0.64 \pm 0.08$ \\
\hline LF-18 & 100 & $11.53 \pm 0.16$ & 1.56 & 100 & 691 & $13.35 \pm 1.87$ & 140 & - & - & - & 100 & 906 & $4.88 \pm 0.58$ & 118 & $0.66 \pm 0.08$ \\
\hline remed. & 100 & $11.15 \pm 0.18$ & 1.80 & - & - & - & - & - & - & - & - & - & - & - & - \\
\hline LF-22 & 100 & $11.68 \pm 0.15$ & 1.56 & 100 & 1297 & 6.260 .66 & 105 & - & - & - & 100 & 814 & $3.93 \pm 0.32$ & 81 & $0.68 \pm 0.08$ \\
\hline LF-23 & 100 & $11.45 \pm 0.18$ & 1.83 & 100 & 553 & $4.75 \pm 0.42$ & 89 & - & - & - & 100 & 664 & $3.21 \pm 0.28$ & 87 & $0.64 \pm 0.07$ \\
\hline TA-1 ( $2^{\text {nd }}$ ext $)$ & - & - & - & - & - & - & - & - & - & - & 100 & 610 & $1.52 \pm 0.10$ & 66 & - \\
\hline
\end{tabular}

Table 2 - Fission-track data of the samples submitted to the second neutron irradiation.

\begin{tabular}{|c|c|c|c|c|c|c|c|c|c|c|c|c|c|c|c|}
\hline Sample & $\mathrm{n}_{\mathrm{Cs}}$ & $\begin{array}{c}\mathrm{L}_{\mathrm{S}^{ \pm}} 1 \sigma \\
(\mu \mathrm{m})\end{array}$ & $\begin{array}{c}\mathrm{S}_{\mathrm{LS}} \\
(\mu \mathrm{m})\end{array}$ & $\mathrm{n}_{\mathrm{s}}$ & $\mathrm{N}_{\mathrm{s}}$ & $\begin{array}{c}\rho_{\mathrm{s}} \pm 1 \sigma \\
\left(\mathrm{x} 10^{5} \mathrm{~cm}^{-2}\right)\end{array}$ & $\mathrm{S}_{\rho s}(\%)$ & $\mathrm{n}_{\mathrm{CI}}$ & $\begin{array}{c}\mathrm{L}_{\mathrm{I}} \pm 1 \sigma \\
(\mu \mathrm{m})\end{array}$ & $\begin{array}{c}\mathrm{S}_{\mathrm{LI}} \\
(\mu \mathrm{m})\end{array}$ & $\mathrm{n}_{\mathrm{I}}$ & $\mathrm{N}_{\mathrm{I}}$ & $\begin{array}{c}\rho_{\mathrm{I}} \pm 1 \sigma \\
\left(\mathrm{x} 10^{5} \mathrm{~cm}^{-2}\right)\end{array}$ & $S_{\rho I}$ & $\mathrm{C} \pm 1 \sigma$ \\
\hline $2^{\text {nd }}$ Irrad & & - & - & - & - & - & - & - & - & - & 200 & 1543 & $1.656 \pm 0.087$ & 75 & - \\
\hline TA-1 ( $1^{\text {st }}$ ext $)$ & - & $11.34 \pm 0.19$ & 1.90 & 100 & 1713 & $14.71 \pm 0.59$ & 40 & - & - & - & 100 & 1062 & $5.13 \pm 0.25$ & 49 & $0.70 \pm 0.08$ \\
\hline LF-2 & 100 & $11.99 \pm 0.16$ & 1.60 & 100 & 1359 & $11.67 \pm 0.58$ & 50 & - & - & - & 100 & 917 & $4.23 \pm 0.19$ & 43 & $0.70 \pm 0.08$ \\
\hline LF-6 & 100 & $11.92 \pm 0.17$ & 1.70 & 100 & 1269 & $24.50 \pm 1.40$ & 58 & 100 & $16.15 \pm 0.09$ & 0.9 & 100 & 1516 & $13.02 \pm 0.93$ & 71 & $0.69 \pm 0.08$ \\
\hline LF-7 & 100 & - & - & - & - & - & - & 100 & $16.58 \pm 0.10$ & 1.0 & 200 & 1663 & $1.795 \pm 0.085$ & 68 & - \\
\hline $\begin{array}{l}\text { TA-1 (center) } \\
\text { LF-10 }\end{array}$ & $\overline{100}$ & $11.05 \pm 0.20$ & 2.03 & 100 & 1544 & $15.05 \pm 0.87$ & 55 & 100 & $15.93 \pm 0.09$ & 0.9 & 100 & 685 & $5.88 \pm 0.33$ & 57 & $0.57 \pm 0.07$ \\
\hline LF-13 & 100 & $11.54 \pm 0.20$ & 2.00 & 100 & 1171 & $22.6 \pm 1.30$ & 59 & - & - & - & 100 & 632 & $12.21 \pm 0.70$ & 57 & $0.64 \pm 0.08$ \\
\hline TA-1 $\left(2^{\text {nd }}\right.$ ext $)$ & - & $\begin{array}{c}11.0+1.20 \\
-\end{array}$ & - & - & - & - & - & - & - & - & 100 & 800 & $1.752 \pm 0.14$ & 83 & - \\
\hline
\end{tabular}

age of the samples belonging to this fault domain was similar to that of the samples collected outside the faults, this reinforced the procedure of adopting the fifth restriction (Fig. 4e) of the samples from outside the faults as a starting restriction for the samples of the old fault domain.

In figure 5 the thermal histories accepted in this region are shown. All these samples imply a heating followed by a linear cooling during the last $\sim 120 \mathrm{Ma}$, as in the case of the samples collected outside of the brittle structures. Besides this thermal behavior, samples LF-2, LF-6 e LF-7 accepts also thermal histories made up by a slow cooling followed by a faster one. However, as our methodology considers the thermal histories of the whole set of samples belonging to a region presenting similar geological characteristics (Hadler et al. 1995, Amaral et al. 1997, Tello et al. $2002 b$ ), the first behavior is the most probable one.

Young fault (Extrema region) The restriction utilized for the samples collected in this fault domain corresponds to the second Monte Carlo box of the first and unique restriction (Fig. 5a) employed for the samples found near the old fault domain (and, also, the second Monte Carlo box of the fifth restriction (Fig. 4e), of the samples collected outside the faults). In this way, the coherence with the age of these samples is maintained and one searches to test if the cooling observed for the two previous group of samples is also observed for these samples.

The thermal histories accepted for each sample of this group are shown in the figure 6 . Analyzing this figure, one sees that both LF-18 sample as LF-18r one, which actually refers to a re- measurement (of the spontaneous tracks length distribution) of LF-18 sample, didn't accept thermal histories for the utilized restriction differently of the other samples belonging to this group, even using 5 times greater amount of tested thermal histories, compared with the other samples.

The thermal histories correspond to a linear cooling during the last $\sim 120 \mathrm{Ma}$, as it is clearly depicted in figure 6 . This behavior agrees with that the old fault domain samples suffered. Following the age analysis (Tables 3 and 4 ) the young fault could be formed between 90 and $160 \mathrm{Ma}$ ago, epoch in which the ending of the heating of the old fault domain and the beginning of the subsequent cooling process took place. This time interval is coincident with time interval corresponding to the second Monte Carlo box both of the first restriction of the old fault domain as the fifth restriction of samples collected outside the faults, as mentioned above.

The results discussed above present good coherence, but taking into account that sample LF-18 (and "LF-18r") did not accept any thermal history, a second treatment, and ruling out LF-18 sample and supposing that the samples found outside the faults belong to the old fault, was performed.

Second treatment In Table 4 the samples are divided in two groups, one made up by the samples collected outside the faults and near the old fault domain and the other formed by young fault domain samples with exception of LF-18 one. Under this procedure the $\chi^{2}$ values both concerning apparent as corrected ages state that the two groups in which the samples were classified present coherence. In that case it is permited to look for a common thermal 
history for each one these groups.

Young fault domain without LF-18 The Monte Carlo boxes were defined similarly to the first treatment using the new values of the mean ages showed in the table. The thermal histories as show in the figure 7 are similar to there of the first tratment.

Old Fault domain and LF-10 and LF-13 samples together In this
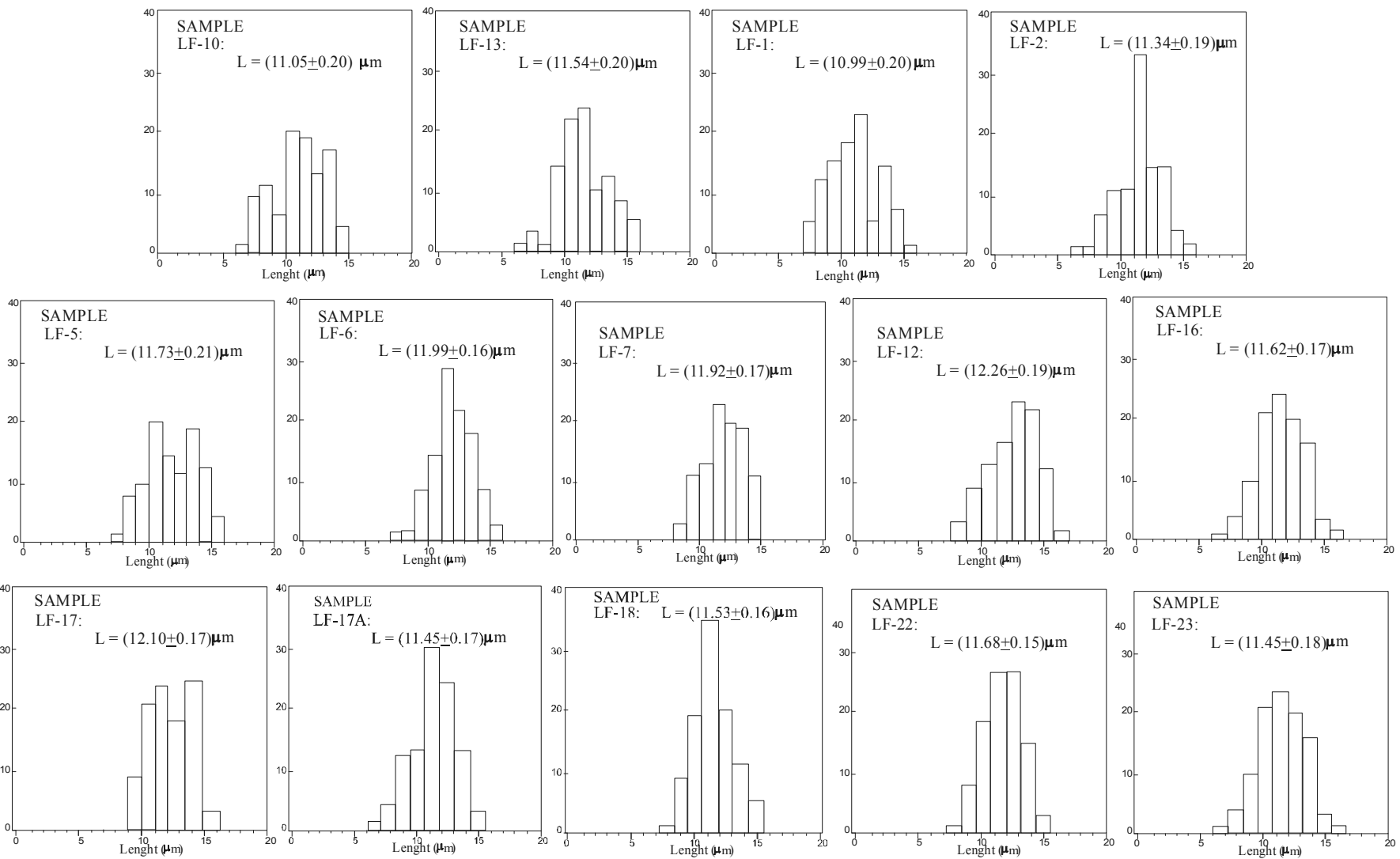

Figure 3 - Spontaneous track length histograms of the samples analysed in this work.Length unit is the micron.
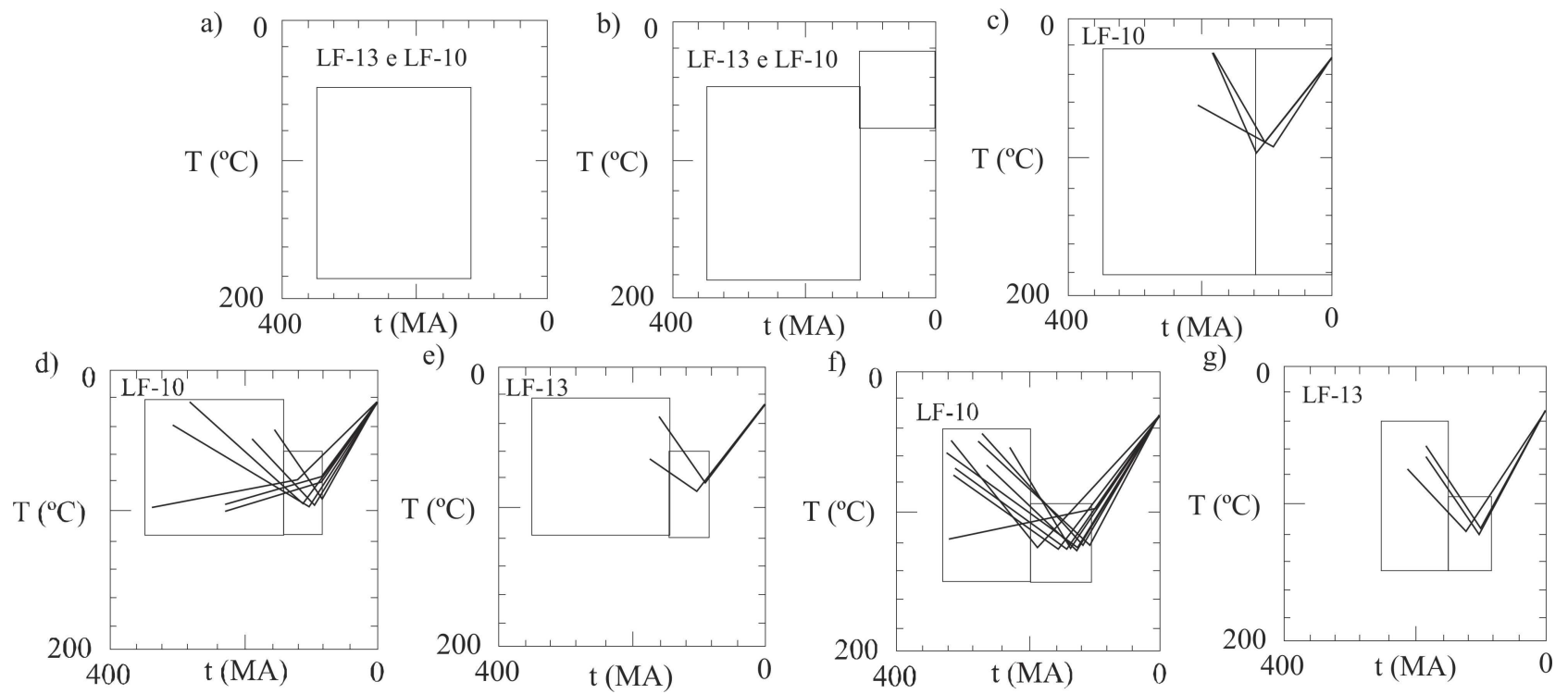

Figure 4 - Thermal histories accepted by the samples collected out of the faults. 
Figure 5 - Thermal histories accepted by the samples placed close to the old faults.

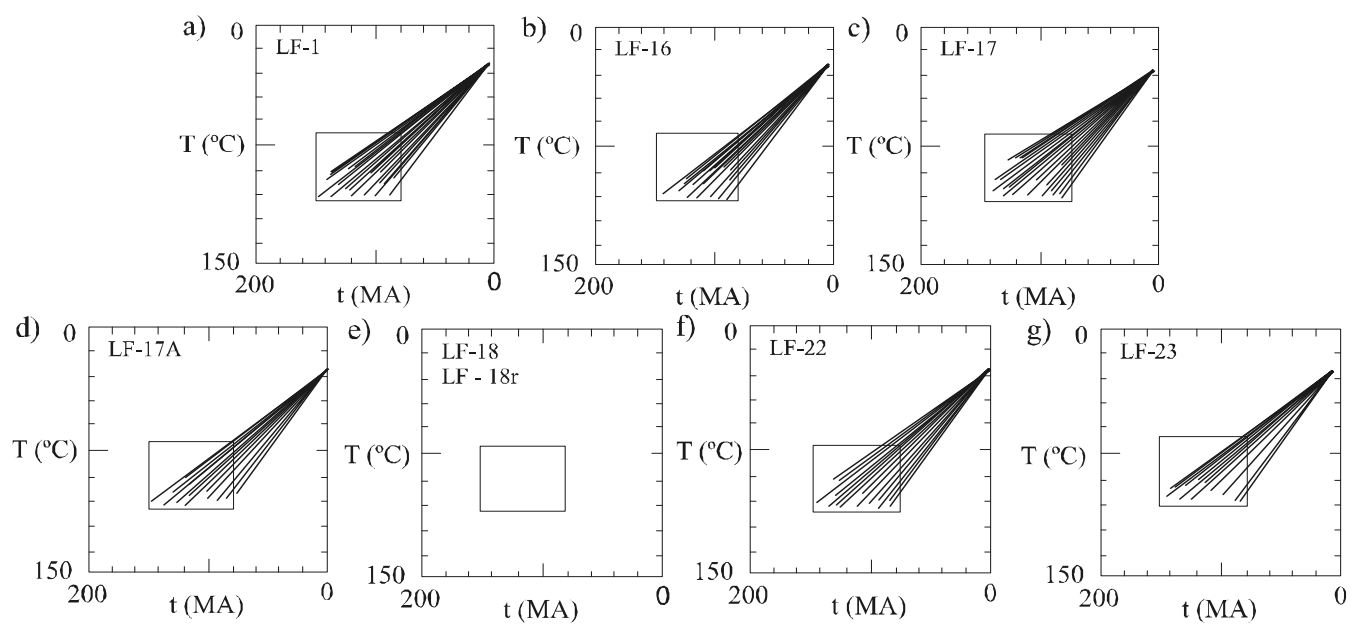

Figure 6 - Thermal histories accepted by the samples found close to the young faults.

case, the second Monte Carlo box was defined with the same dimensions, in time and temperature, as those of the box to the group of samples of the young fault domain (without LF-18 sample). The first box was built using the new value of the corrected average age, given in Table 4 , and the temperature interval calculated as in the first treatment.

The thermal histories accepted are depicted in figure 8. It is important to point out that this treatment (the second one) was performed in the inverse order of the first one, because in the former the young fault domain was analysed first. However both treatments presented thermal histories that are statistically the same, indicating that the employed methodology is coherent.

Finally, the assumption that LF-18 sample belongs to the old fault domain finds a reasonable support in the fact that the corresponding apparent and corrected ages are statistically equal (see Table 3). The thermal histories for LF-18 and LF-18r (sample LF -18 with more interactions) were obtained considering that assumption and, consequently, applying to that sample the same restriction imposed to the old fault domain samples in the first treatment. The accepted thermal histories are shown in figure 9, where one can see a satisfactory amount of accepted histories presenting a behavior similar to that of the old fault domain samples (Fig. 8). This indicates that LF-18 sample should belong to the old fault domain.

Among the references about the employment of TFM to the study of thermal events, it is worthwhile to make some specific remarks on the ones of Gallagher et al. 1994 and Gallagher et al. 1995 , because some of the samples analysed in their work were collected near the region studied by us. Two samples analysed by them (in their notation, samples number 34 , latitude $22.94^{\circ} \mathrm{S}$ and longitude $46,70^{\circ} \mathrm{W}$, and 35 , latitude $23.06^{\circ} \mathrm{S}$ and longitude 46.53 ${ }^{\circ} \mathrm{W}$ ) were found inside the area studied by us; these samples present mean track length and length histogram shapes very similar to those we obtained for the samples found near and far the old faults, although the apparent ages they measured are greater than ours. The thermal histories of these two samples were not shown in their work. However, there is good similarity between their and our thermal histories in two cases (samples number 44, latitude $22.08^{\circ} \mathrm{S}$ and longitude $46.21^{\circ} \mathrm{W}$, and 46 , latitude $22.21^{\circ} \mathrm{S}$ and longitude $45.90^{\circ} \mathrm{W}$ ) related to samples collected not far from the region we studied. This agreement also occurs concerning mean track length and length histogram shape.

The summary, our methodology indicates that the young fault domain was formed $\sim 120 \mathrm{Ma}$ and was not submitted to a later reactivation up to the present. In addition, the thermal history accepted by all samples collected both outside as near the old fault domain is a heating that took place between $\sim 200$ and $\sim 120$ Ma ago followed by a linear cooling phase until the present time, indicating that both the country rocks as the rocks collected near the old fault domain were reactivated during the movements registered in the young fault domain.

DISCUSSION AND CONCLUSIONS The results of FTM in samples collected near Bragança Paulista-SP in faults with pseudotachylytes and denominated here old fault domain. These results are in agreement, both in age and thermal histories, between samples found in and far from the old fault domain ( 190 Ma). Modeled thermal histories began to be recorded, at that time, at 
Table 3.- Fission-track ages and $\chi c^{2}$ test of the samples analysed in this work dividing them in three domains: outside the faults and close to the young and old faults.

\begin{tabular}{|c|c|c|c|c|c|c|c|c|c|}
\hline \multirow[b]{2}{*}{ Region } & \multirow[b]{2}{*}{ Sample } & \multirow[b]{2}{*}{$\mathrm{T}_{\mathrm{AP}}(\mathrm{Ma})$} & \multirow[b]{2}{*}{$\mathrm{T}_{\text {corr }}(\mathrm{Ma})$} & \multicolumn{2}{|c|}{ Mean Age } & \multicolumn{4}{|c|}{ Test $\chi^{2}$} \\
\hline & & & & \multirow[t]{2}{*}{$\mathrm{T}_{\text {ap }}(\mathrm{Ma})$} & \multirow[t]{2}{*}{$\mathrm{T}_{\text {corr }}(\mathrm{Ma})$} & \multicolumn{2}{|c|}{ Mean apparent age } & \multicolumn{2}{|c|}{ Mean corrected age } \\
\hline & & & & & & $\chi_{v}{ }^{2}$ & $\overline{P_{\gamma}}$ & $\chi_{v}{ }^{2}$ & $\overline{\mathrm{P}_{\gamma}}$ \\
\hline \multirow[t]{4}{*}{ Outside the faults } & LF-10 & $155 \pm 25$ & $267 \pm 53$ & $126 \pm 16$ & $200 \pm 30$ & 2.15 & $\approx 0.15$ & 2.35 & $\approx 0.10$ \\
\hline & LF-13 & $108 \pm 20$ & $168 \pm 37$ & $\sigma_{\exp }=24$ & $\sigma_{\text {exp }}=50$ & $v=1$ & & $v=1$ & \\
\hline & LF-1 & $120 \pm 20$ & $207 \pm 44$ & & & & & & \\
\hline & LF-2 & $127 \pm 22$ & $180 \pm 36$ & & & & & & \\
\hline \multirow[t]{8}{*}{ Old fault domain } & LF-5 & $124 \pm 20$ & $191 \pm 38$ & $125 \pm 9$ & $188 \pm 17$ & 0.42 & $\approx 0.80$ & 0.29 & $\approx 0.22$ \\
\hline & & & & $\sigma_{\exp }=7$ & $\sigma_{\text {exp }}=9$ & $v=4$ & & $v=4$ & \\
\hline & LF-6 & $153 \pm 25$ & $216 \pm 43$ & & & & & & \\
\hline & LF-7 & $114 \pm 19$ & $165 \pm 33$ & & & & & & \\
\hline & LF-12 & $110 \pm 20$ & $155 \pm 33$ & & & & & & \\
\hline & LF-16 & $68 \pm 11$ & $103 \pm 20$ & & & & & & \\
\hline & LF-17 & $56 \pm 8$ & $79 \pm 15$ & & & & & & \\
\hline & LF-18 & $136 \pm 31$ & $205 \pm 52$ & & & & & & \\
\hline \multirow[t]{4}{*}{ Young fault domain } & $\mathrm{LF}-17^{\mathrm{A}}$ & $95 \pm 13$ & $148 \pm 26$ & $73 \pm 5$ & $110 \pm 9$ & 2.56 & $\approx 0.02$ & 1.98 & $\approx 0.05$ \\
\hline & & & & $\sigma_{\exp }=10$ & $\sigma_{\exp }=16$ & $v=6$ & & $v=6$ & \\
\hline & LF-22 & $80 \pm 15$ & $118 \pm 26$ & & & & & & \\
\hline & LF-23 & $74 \pm 13$ & $116 \pm 25$ & & & & & & \\
\hline
\end{tabular}

Table 4 - Fission-track ages and $\chi^{2}$ test dividing the samples studied here in two groups.

\begin{tabular}{|c|c|c|c|c|c|c|c|c|c|}
\hline \multirow{3}{*}{ Region } & \multirow{3}{*}{ Sample } & \multirow{3}{*}{$\mathrm{T}_{\mathrm{ap}}(\mathrm{Ma})$} & \multicolumn{3}{|c|}{ Mean age } & & \multicolumn{3}{|c|}{ Test $\chi^{2}$} \\
\hline & & & $\mathrm{T}_{\text {corr }}(\mathrm{Ma})$ & $\mathrm{T}_{\text {ap }}(\mathrm{Ma})$ & $\mathrm{T}_{\text {corr }}(\mathrm{Ma})$ & \multicolumn{2}{|c|}{ Mean apparent age } & \multicolumn{2}{|c|}{ Mean corrected age } \\
\hline & & & & & & $\chi_{v}{ }^{2}$ & $\mathrm{P}_{\chi}$ & $\chi_{v}{ }^{2}$ & $\mathrm{P}_{\chi}$ \\
\hline $\begin{array}{l}\text { Outside the } \\
\text { faults and } \\
\text { old fault }\end{array}$ & $\begin{array}{l}\text { LF-10 } \\
\text { LF-13 }\end{array}$ & $\begin{array}{l}155 \pm 25 \\
108 \pm 20\end{array}$ & $\begin{array}{l}267 \pm 53 \\
168 \pm 37\end{array}$ & & & & & & \\
\hline domain & $\begin{array}{l}\text { LF-1 } \\
\text { LF-2 } \\
\text { LF-5 } \\
\\
\text { LF-6 } \\
\text { LF-7 } \\
\text { LF-12 } \\
\text { LF-16 } \\
\text { LF-17 }\end{array}$ & $\begin{array}{c}120 \pm 20 \\
127 \pm 22 \\
124 \pm 20 \\
\\
153 \pm 25 \\
114 \pm 19 \\
110 \pm 20 \\
68 \pm 11 \\
56 \pm 8\end{array}$ & $\begin{array}{c}207 \pm 44 \\
180 \pm 36 \\
191 \pm 38 \\
\\
216 \pm 43 \\
165 \pm 33 \\
155 \pm 33 \\
103 \pm 20 \\
79 \pm 15\end{array}$ & $\begin{array}{l}126 \pm 8 \\
\sigma_{\exp }=7\end{array}$ & $\begin{array}{l}191 \pm 15 \\
\sigma_{\exp }=13\end{array}$ & $\begin{array}{c}0.64 \\
v=6\end{array}$ & $\approx 0.7$ & $\begin{array}{c}0.61 \\
v=6\end{array}$ & $\approx 0.7$ \\
\hline $\begin{array}{l}\text { Young fault } \\
\text { Domain }\end{array}$ & $\begin{array}{l}\text { LF-17A } \\
\text { LF-22 } \\
\text { LF-23 }\end{array}$ & $\begin{array}{l}95 \pm 13 \\
80 \pm 15 \\
74 \pm 13\end{array}$ & $\begin{array}{l}148 \pm 26 \\
118 \pm 26 \\
116 \pm 25\end{array}$ & $\begin{array}{c}72 \pm 5 \\
\sigma_{\exp }=8\end{array}$ & $\begin{array}{l}107 \pm 9 \\
\sigma_{\exp }=12\end{array}$ & $\begin{array}{l}2.24 \\
v=5\end{array}$ & $\approx 0.07$ & $\begin{array}{l}1.69 \\
v=5\end{array}$ & $\approx 0.10$ \\
\hline
\end{tabular}

$\sim 50^{\circ} \mathrm{C}$ meaning probably that temperature lowered fast so that no samples were able to register the passing through the partial annealing zone $\left(120^{\circ} \mathrm{C}\right.$ to $\left.60^{\circ} \mathrm{C}\right)$. The Geomorphologic analysis in the relief of old fault domain are affected by successive stages of downcutting, which will lead to preservation of the older palaeosurfaces on high plateau, is probably, of the Japi Surface (or Gondwana). This is consistent with a thermal event, taking place at that time (Fig. 10B).

The tectonic relationed to the fast cooling registered in thermal histories, consists the brittle tectonic movements related to initial phase of the developing marginal rift basins in the South Atlantic (Karner \& Driscoll, 1999) and reactivation of older faults (Ribeiro, 2003).

The FTM shows a slow linear heating from $\sim 50$ to $\sim 90^{\circ} \mathrm{C}$ between the Upper Triassic ( $\sim 190 \mathrm{Ma})$ and the Cretaceous $(\sim 120$
Ma), related to high elevation of coast of Brazil and Africa due the fragmentation of Gondwana (Park \& Jaroszewski, 1994, Karner \& Driscoll, 1999). The linking of adjacent rifts led to the full development of the ridge transform boundary, and at the beginning, between the Late Jurassic and Cretaceous, of the separation of the South American and African Plates. In the Cretaceous ( 120Ma), the heating is due to the further regional uplift and lithosphere thinning along the newly formed divergent margin and the extrusion of basic magmas of Parana - Etendeka flood basalt volcanism (Turner et al. 1994, Ernesto et al. 2002). Criteria as the development of new palaeosurfaces in high plateaux on the Mantiqueira mountain range suggest a long-term surface formation indicate uplift of Mantiqueira Mountain range. A vertical subsidence cannot be the answer for the gradual temperature increasing between the Upper Triassic and Cretaceous, in reason of the geological and 
Phanerozoic brittle tectonics in the South American Continental Platform, southeast Brazil: new insights from Fission Track studies on apatite in reactivated fault zones
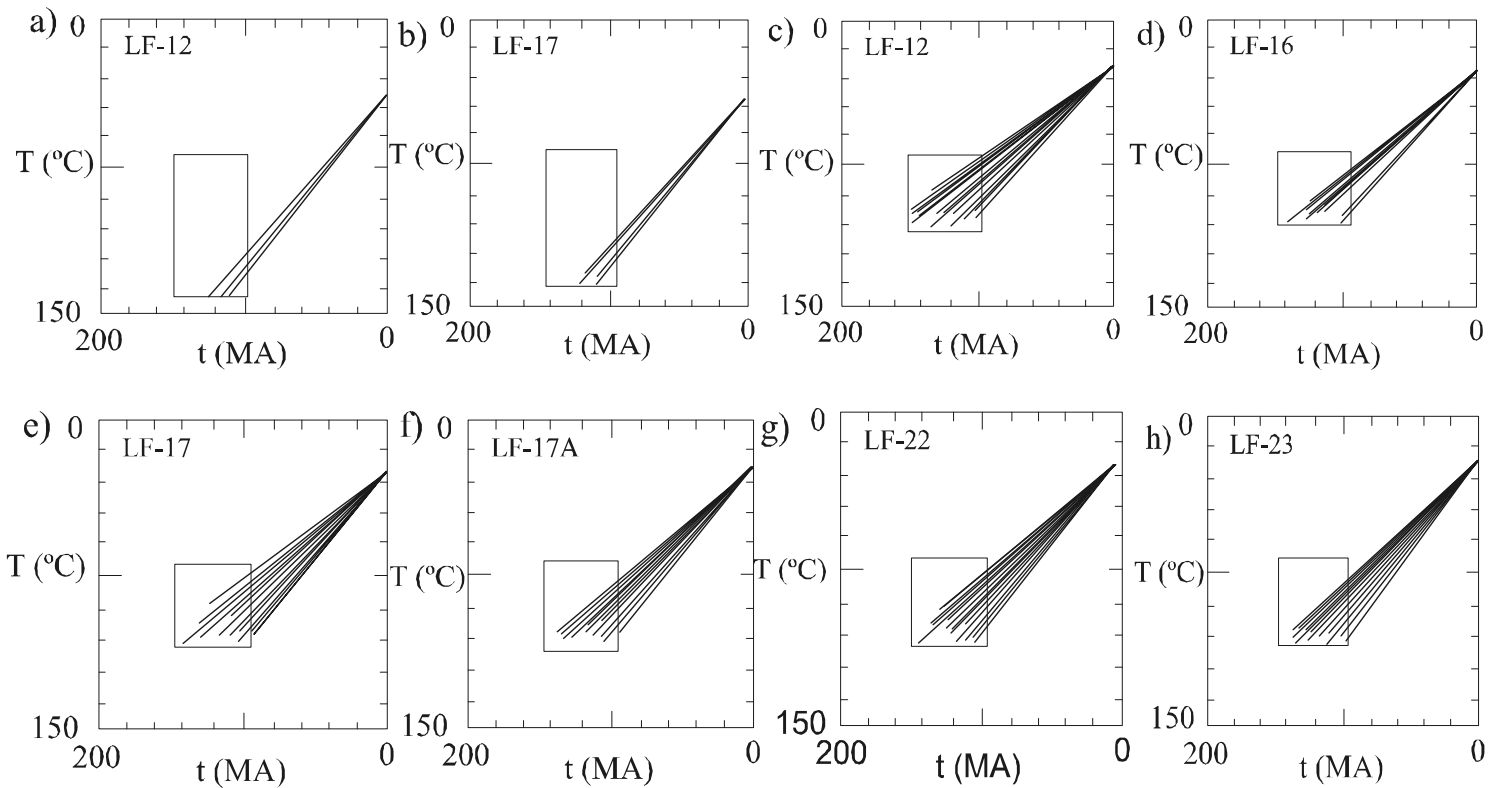

Figure 7 - Thermal histories accepted in the second treatment by the samples located close to the young faults.
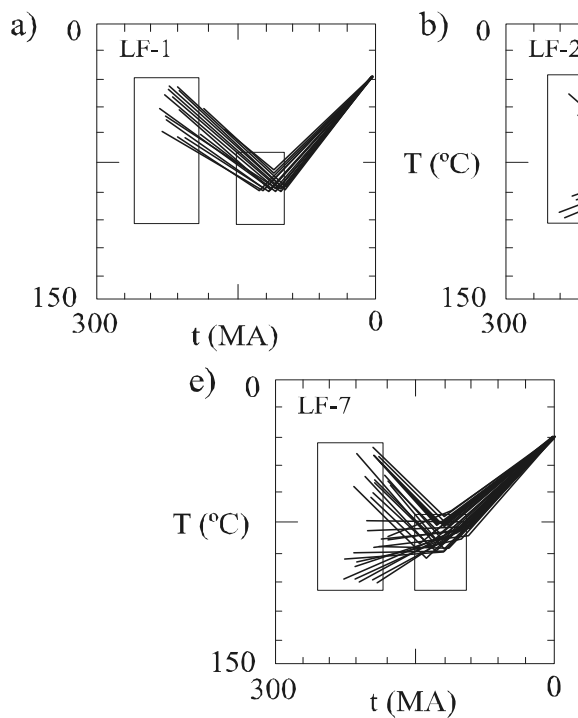
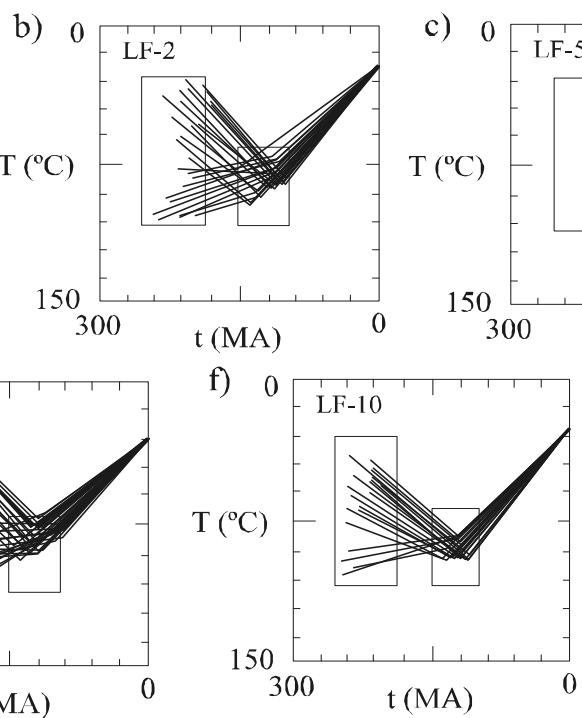
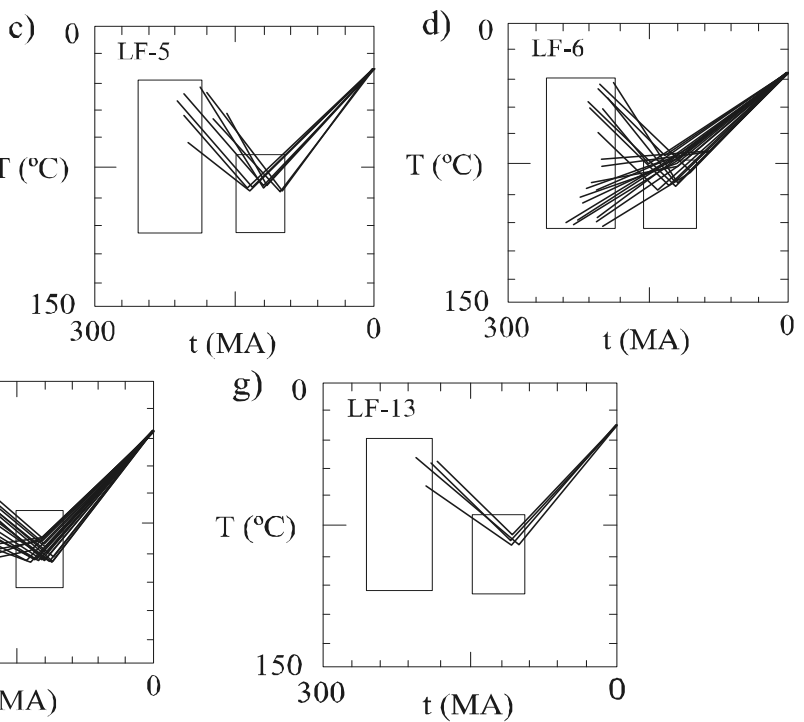

Figure 8 - Thermal histories accepted in the second treatment by the set of samples made up by those localized close to the old faults plus $L F-10$ and LF-13 ones

geomorphological remarks presented above.

The FTM data shows that at $\sim 120 \mathrm{Ma}$ an inversion of the thermal behavior occurred. Samples with a prior heating began to cool down, related to denudation (Fig. 10D). The younger faults were formed at that time and the older ones reactivated. The Mantiqueira mountain range was formed at that time by a rapid uplift. At that time the Japi surface was uplifted around $1000 \mathrm{~m}$ (Fig. 10C). The process was related to the South-Atlantic opening, extensive faulting and a widespread extensional tectonic along the southeastern Brazilian coast. During this time alkaline, ultrapotassic and ultramafic intrusions, were emplaced along some of the reactivated strike-slip faults and transfer zones. Renewed tectonic subsidence in the region of the Parana Basin resulted in
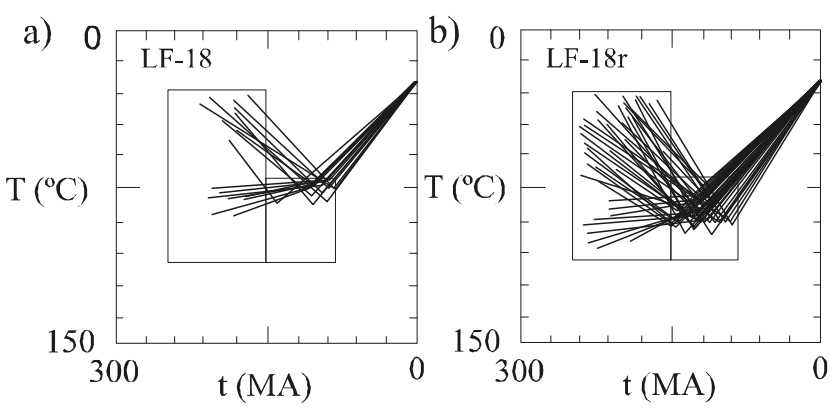

Figure 9 - Thermal histories accepted in the first treatment by LF-18 and LF 18 r samples, considering that they belong to the old faults. 

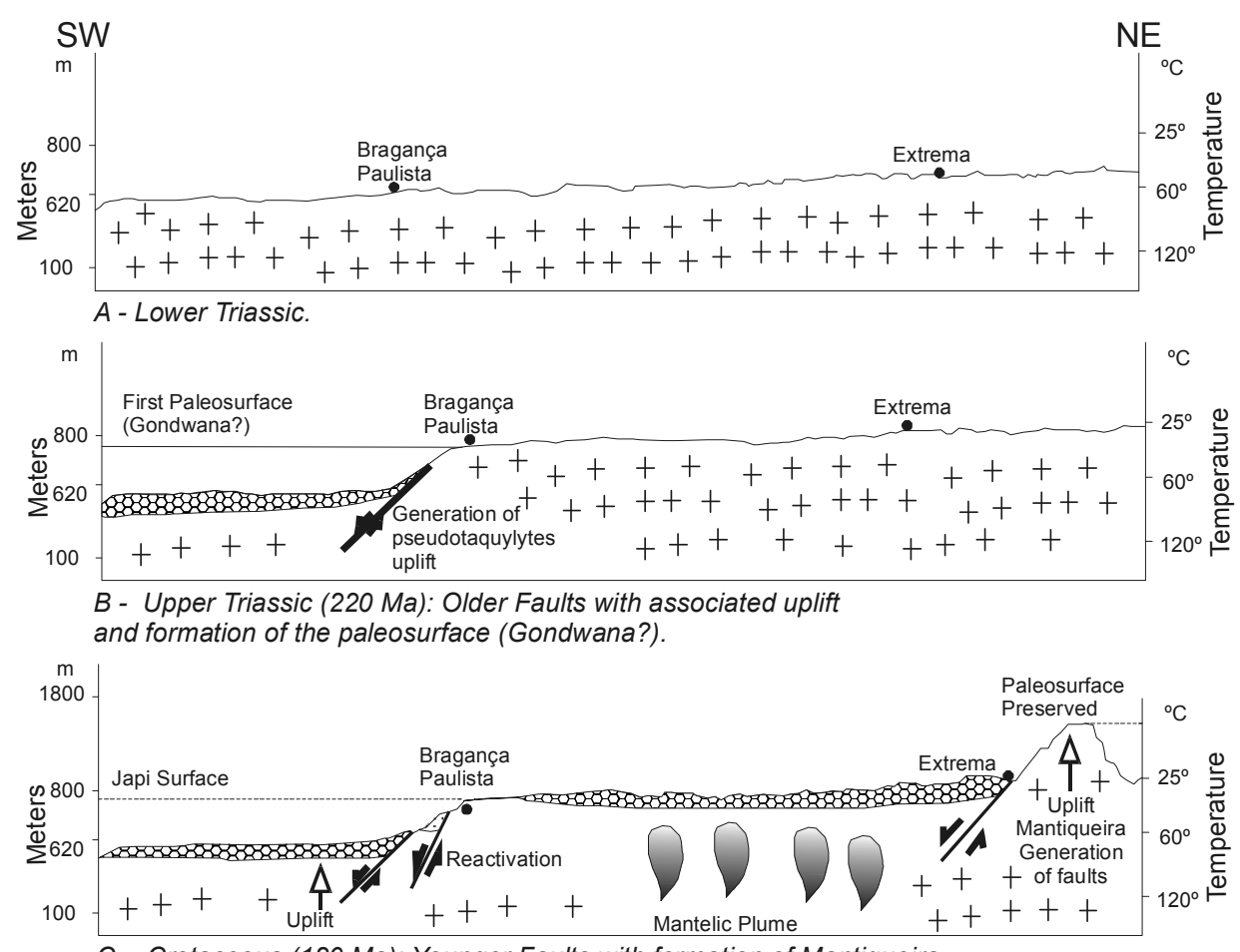

C - Cretaceous (120 Ma): Younger Faults with formation of Mantiqueira Mountain range and uplift of the first paleosurface.

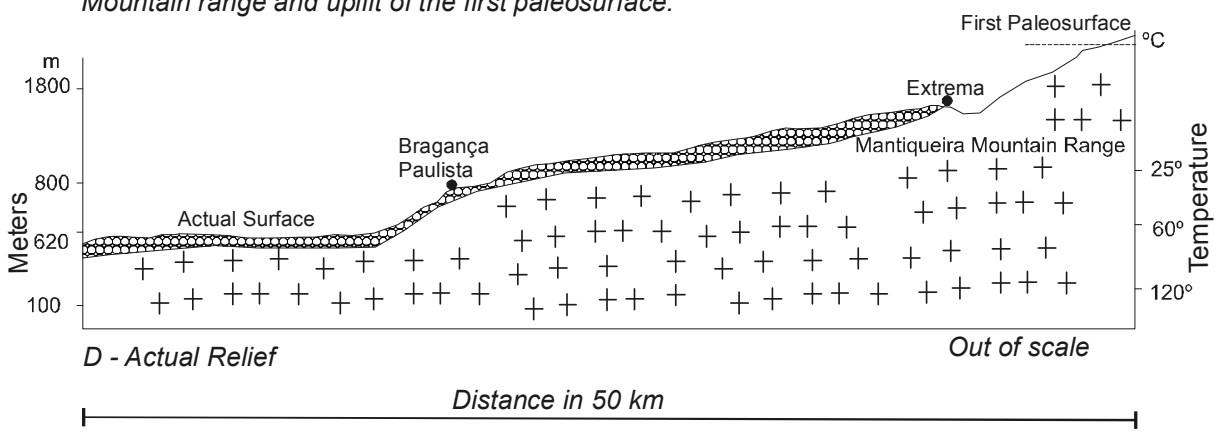

Figure 10 - Sketch with the Phanerozoic evolution of the Mantiqueira mountain range relating faults with geomorphologic feature, based on FTM on apatite of faulted rocks. Relative altitudes and temperatures obtained through FTM are shown on the left and right ordinates, respectively. See the text for a better explanation.

the deposition of the Caiuá Formation.

The data resulting from our apatite fission track studies and structural observations have provided new insights regarding the reconstruction of the thermal and chronological history in our study area of SE Brazil., indicating that Jundiaí upland plain the faults were formed between $\sim 200$ and $\sim 120$ Ma under a compressional regime, followed by a linear cooling relationed to formation of the palaeosurfaces. In addition, Mantiqueira mountain range was formed $\sim 120 \mathrm{Ma}$ ago, with reactivations of compression nature of faults followed by uplift and erosion, corroborating the geomorphologic evidences of superimposition of successive palaeosurfaces.
FTM methodologies are useful tool in the study of the country rocks associated to faults, tectonic reactivated and to auxiliary in geomorphologic studies.

Acknowledgements To Dr. K. Gallagher for the corrections and suggestions that improved greatly this work and to Dr. C.W. Naeser for providing the Durango apatite samples. The work of Hackspacher at the Universidade Estadual Paulista is partially supported by CNPq (Grant 464173/00-0 and 550619/2002-0) and FAPESP (Grant 95/4417-3 and 00/03960-5). Tello is supported by FAPESP (Grant 01/07937-0). To the RBG referees for sugtgestions to the manuscript..

\section{References}

Almeida F.F.M., 1967. Origem e evolução da Plataforma Brasileira. Bol. Div. de Geol. e Min., DNPM, 241:36p.

Amaral G., Born H., Hadler N.J.C., Iunes P.J., Kawashita K., Machado Jr. D.L,OliveiraE.P., Paulo S.R., Tello S.C.A. 1997. Fission track analisys of apatites from São Francisco Craton and Mesozoic AlcalineCarbonatite complexes from central and southeastern Brazil. J. South. Am. Earth Science, 10:285-294. 
Phanerozoic brittle tectonics in the South American Continental Platform, southeast Brazil: new insights from Fission Track studies on apatite in reactivated fault zones

Almeida F.F.M. \& Ponçano W.L.1993. Superfícies erosivas nos planaltos cristalinos do leste paulista e adjacências: uma revisão. Cadernos do I.G. Unicamp, Campinas, SP, Brazil, 3:55-90.

Artur A.C. 1980. Rochas metamórficas dos arredores de Itapira - S.P. Dissertação de mestrado, IG/USP, SP. Brazil, 193p.

Artur A.C. 1988.Evolução policíclica da infraestrutura da porção sul do estado de Minas Gerais e regiões adjacentes do estado de São Paulo. Tese de Doutorado, IG/USP, SP; Brazil, 231p.

Asmus H.E. \& Ferrari A.L. 1978. Hipótese sobre a causa do tectonismo cenozóico na região sudeste do Brasil. In: Aspectos estrutural da margem continental leste e sudeste do Brasil. Projeto REMAC 4, Petrobrás/Cempes/Dintep, p. 75-88.

Bigazzi G. 1967.Lenght of fission track and the age of muscovite samples. Earth and Planetary Science Letters, 3: 313-318.

Bistrichi C.R. 2001.Análise estratigráfica e geomorfológica do cenozóico da região de Atibaia-Bragança Paulista, Estado de São Paulo. Tese de doutorado, IGCE, Unesp, Rio Claro, 184p.

Carlson D.W., Donelick R.A., Ketcham R.A. 2000.Variability of apatite fission-track annealing kinetics: I. Experimental results. American Mineralogist, 84:1213-1223.

Crowley K.D., Cameron M., Shaefer R.L. 1991. Experimental studies of annealing of etched fission track in fluorapatite.Geochimic et. Cosmochimic Acta. 55:1449-1465.

Ebert H.D., Artur A.C., Chemale Jr. F., Babinski M., Van Schmus W.R. 1996. Tectonic setting and $\mathrm{U} / \mathrm{Pb}$ zircon dating of the plutonic Socorro Complex in the transpressive rio Paraíba do Sul shear belt, SE Brazil. Tectonics, 15(2):688-699.

Ernesto M., Marques L.S., Piccirilo E.C., Molina E.C., Ussami N., Comin - Chiaramonti P., Bellieni G. 2002. Paraná Magmatic Province Tristan da Cunha plume system: fixed versus móbile plume, petrogenetic considerations and alternative heat source. $J$. Vulcanology and Geothermal Research, 2484:1-22.

Cordani U.G., Milani E.J., Thomaz Filho A., Campos D.A.2000. Tectonic Evolution of south America. Rio de Janeiro. 854p., 31th Intern. Geol. Congr.., Publicação Especial.

Cox R.T. 1989. The role of mantle plume in the development of continental drainage patterns, Nature, 342:21-28.

Fernandes F.L. 1993. Arcabouço estrutural e evolução da bacia de Taubaté - SP. Tese de Mestrado. Departamento de Geologia da Escola de Minas de Ouro Preto, MG, Brasil, 155p.

Fetter A.H., Hackspacher P.C., Hadler Neto J.C., Iunes P.J., Paulo S.R., Ribeiro L.F.B., Tello C.A 2001. New Sm/Nd and U/Pb geochronological constraints on the Archean to Neoproterozoic evolution of the Amparo Basement Complex of the Central Ribeira Belt, southeastern Brazil. South Amer. Symp. Isotope Geology,3, Pucón - Chile, Abbreviated Abstracts Volume, p.36

Françolin J.B.L., Zanotto O.A., Szatmari P. 1996. Análise estrutural de eventos pós-jurássicos na bacia do Paraná. In: SBG, Congr. Bras. Geol. 39, 5:381-384.

Fúlfaro V.J., Oliveira M.A.F., Morales N., Souza Filho E.E. 1985. Evolução cenozóica da região de Atibaia, SP. In: SBG, Simp. Reg. Geologia, 5, São Paulo, pp. 315-321.

Gallagher K. \& Hawkesworth C.J., 1994. Mantle plumes, continental magmatism and asymetry in the South Atlantic. Earth and Planetary Science Letters, 123:105-117.

Gallagher K., Hawkesworth C.J., Mantovani M.S.M. 1994. The denudation history of the onshore continental margin of SE Brazil inferred from apatite fission track data. J. Geophys. Res.,
99(B9):18117-18145.

Gallagher K., Hawkesworth C.J., Mantovani M.S.M. 1995. Denudation fission track analysis and long term evolution of passive margin topography: application to the southeast Brazilian margin. J. South Amer. Earth Sciences, 8:65-77.

Gibson S.A., Thompson R.N., Leonardos O.H., Dickin A.P., Mitchell J.G. 1995. The late Cretaceous impact of the Trindade mantle plume: evidence from large volume, mafic, potássico magmatismo in SE Brazil. J. Petrology, 36:189-229.

Green P.F., Duddy I.R., Gleadow A.J.W., Tingate P.R., Laslett G.M. 1986. Thermal annealing of fission tracks in apatite, 1. A quantitative description. Chem. Geol. (Isot. Geosci. Sect.), 59:237-253.

Guedes S., Hackspacher P.C., Hadler Neto, J.C.; Iunes P.J., Paulo S.R., Ribeiro L.F.B., Tello C.A. 2000. recognition of cretaceous, paleocene and plio - pleistocene activities, through afta, in precambrian areas of the soutest brazil: association with the South Atlantic ocean opening. In: Intern. Confer. Fission Track Dating e Geological Thermochron., 9 Australia, Abstracts... Australia, 2000, p.139-141.

Hackspacher P.C., Ribeiro L.F.B, Ribeiro M.C.S., Fetter A.H., Hadler Neto J.C., S. Tello C.A., Dantas E.L. 2004. Consolidation and break - up of the South American platform in southeastern Brazil: tectonothermal and denudation histories. Gondw. Res., 7:91-101.

Hadler N., J.C., Iunes P.J., Paulo S.R., Tello S. C.A. 1995. Obtainment of thermal histories for sets of geologically compatible localities by using apatite fission track analysis. Rev. Física Aplicada e Instrumentação, 10:p.1-10.

Hamza V.M., Frangipani A., Becker E.A., Mioto J.A. 1989. Mapas geotermais do Brasil. Relatório interno do Instituto de Pesquisas Tecnológicas, SP. Brasil, IPT - nº 27069.

Hasui Y. \& Oliveira M.A.F. 1984. Província Mantiqueira - Setor Central - In: Y. Hasui \& f.F.M. Almeida (Coords.), O Precambriano do Brasil. Editora Edgard Blucher, SP, p.308-344.

Hurford A.J. 1990. Standardization of fission track dating calibration: recomendation by the Fission Track Working Group of the I.U.G.S. Subcommission on Geochronology. Chem. Geol. (Isot. Geosci. Sect.), 80:171-178.

Iunes P.J., Hadler, N. J.C., Bigazzi G., Tello S.C.A., Guedes S., Paulo S.R. 2002. Durango apatite fission-track dating using length-based age corrections and neutron fluence measurements by natural thorium thin films and natural U-doped glasses calibrated through natural uranium thin films. Chemical Geology, 187:201-211.

Jaffey A.H., Flynn K.F., Glendenin L.E., Benttley W.C., Essling A.M. 1971. Precision measurements of the half-lives and specific activities of U-238. Physical Review, 4:1989-1906.

Karner G.D., \& Driscoll N.W. 1999.Tectonic and stratigraphic development of the West African and eastern Brazilian Margins: insight from quantitative basin modeling. In: N.R. Cameron, R.H. Bate \& V.S. Clure (eds) The Oil and Gas Habitats of the South Atlantic. Geological Society, London, Special Publications, 153:11-40.

Laslett G.M., Kendall W.S., Gleadow A.J.W., Duddy I.R. 1987. Bias in measurement of fission -track length distributions. Nuclear Tracks, 6:79-85.

Lima C., Cobbold P.R., Soudarin L. 1997 Topographic and structural expressions of Andean-related tectonics in midplate South America. In: SBG, Simp. Nac. Estudos Tectônicos, 5, Atas, p.27-30.

Lutz T.M. \& Omar G. 1991. An inverse method of modeling thermal histories from apatite fission-track data. Earth Planet. Sci. Letters, 104:181-195.

Macedo M.J., Bacoccoli G., Gamboa L.A.P. 1991. O tectonismo meso- 
cenozóico da região sudeste. In: SBG, Simp. Geol. Sudeste, SãoPaulo p. 429-437.

McKenzie D.P. 1984. A possible mechanism for epeirogenic uplift. Nature, 307:616-618.

Milani E.J. \& Ramos V. 1998. Orogenias paleozóicas no domínio sul ocidental do gondwana e os ciclos de subsidência da Bacia do Paraná, Rev. Bras. Geoc., 28:473-484.

Oliveira M.A.F., Morales N., Fúlfaro V.J., Campos, E.G. 1985. Projeto Atibaia: geologia da quadrícula de Atibaia. Final Report, PRÓ-MINÉRIO - UNESP, SP, Brazil, 117p.

Pigeon P.1985. Les releves de látlantique Sud vous dones le bordiers de continents en Angola et au Brésil: notion la du vers de thermiques du relifs. Geociências, 4:77-86

Ponçano W.L. 1981. As coberturas cenozóicas. In: IPT/DMGA, Mapa Geológico do Estado de São Paulo, escala 1:500.000. São Paulo, 1: $82-102$.

Price, P.B., and Walker R.M., 1963. Fossil tracks of charged particles in mica and the age of the minerals. Journal of Geophysical Research, 68 (16): p. $4.847-4.862$

Ribeiro L.F.B. 1996. Tectônica ressurgente da borda sul da serra da Mantiqueira: geologia estrutural e geocronologia por traços de fissão. Tese de Mestrado, Instituto de Geologia e Ciências Exatas, UNESP - Rio Claro, SP, Brazil, 121 p.

Ribeiro L.F.B., Hackspacher P.C., Hadler Neto J.C., Iunes P.J., PauloR.S 1999. Considerações sobre o Sistema de Falhas de Extrema na região entre Bragança Paulista (SP) e Extrema (MG) através da análise petroestrutural de pseudotaquilitos, cataclasitos e quartzo azul. VII Simpósio Nacional de estudos tectônicos - Lençóis Bahia Brazil, Anais... sessão p.24 -26.

Ribeiro L.F. B. 2003. Morfotectônica da região centro leste do estado de são Paulo e adjacências de Minas Gerais: Termocronologia e Paleotensões. Tese de Doutoramento IGCE/UNESP. Rio Claro - SP. $195 \mathrm{p}$.

Riccomini C. 1995.Tectonismo gerador e deformador dos depósitos sedimentares Pós-Gondvânicos da porção Centro-Oriental do estado de São Paulo. Livre-docência, IG/USP, Brazil, 100p.

Schobbenhaus C., Campos D.A., Derze G.R, Asmus H.E. (cords.), 1981 Mapa geológico do Brasil e da área oceânica adjacente incluindo depósitos minerais, escala 1:2.500.000. Brasília, DF, DNPM, 4 p.

Shreider U.A. 1966. The Monte Carlo Method. Pergamon Press, New
York,266p.

Storzer D. \& Wagner G.A., 1969. Correction of thermally lowered fission track ages of tektites. Earth Planet. Sci. Letters, 5:163-168.

Tello S.C. A., 1994. Thermocronologia de algumas regiões brasileiras através da análise de traços de fissão em apatitas. Dissertação de Mestrado, IFGW, UNICAMP, Campinas, SP, Brazil, 103p.

Tello S.C. A., Hadler N., Iunes P.J., Paulo S.R., Guedes S. 2002 a. Annealing studies in apatite trough fission track density and length measurements in basal and randomly oriented faces. Submited to American Mineralogist.

Tello S.C.A., P. Hackspacher J.C., Hadler N., Iunes P.J., Guedes S., Paulo S.R., Ribeiro L.F. 2002. Recognition of Cretaceus, Paleocene and Neogene tectonic reactivation, through apatite tission-track analysis, in Precambrian areas of the Southeast Brazil: association with the South Atlantic Ocean opening. J. South Am. Earth Science, 15:765-774.

Turner S.P., Hawkesworth C.J., Gallagher K., Stewart K., Peate D., Mantovani M. 1996 Mantle plumes, flood basalts and thermal models for melt generation beneath continents: assessment of a conductive heating model. J. Geoph. Res., 101:11503-11518.

Van Decar J.C., David E.J, Assumpção M. 1995. Seismic evidence for fossil mantle plume beneath South America and implications for plate driving forces. Nature, 378: November, $2^{\text {nd }}$.

Wagner G.A. 1968. Fission Track dating of apatites. Earth Planet. Sci. Letters, 5:463-468.

Wagner G.A. \& Van Den Haute 1992. Fission-track dating. Kluwer Acad., Norwell, Mass, 285p.

Wernick E. 1978. Contribuição à estratigrafia do Pré-Cambriano no leste do estado de São Paulo e áreas vizinhas. Rev. Bras. Geoc., 8:206216.

Zálan P.V., Wolf S., Conceição J.C.J., Marques A., Astolfi M.A.M., Vieira I.S., Appi V.T., Zanotto O.A. 1990. Bacia do Paraná. In: G.P. de Raja Gabaglia \& E.J. Milani (Cords.), Origem e evolução de bacias sedimentares. Petrobrás, pp. 135-168.

Manuscrito A 1414

Recebido em 06 de fevereiro de 2003

Revisão dos autores em 30 de dezembro de 2004 Revisão aceita em 25 de janeiro de 2005 


\section{APPENDIX}

i) "Length bias" correction (Laslett et al., 1982): It is well known that annealing can shorten the length of fission tracks. Then, the probability that a confined track in apatite crosses some crystallographic lattice dislocation or some other track reaching the observed surface is reduced through the annealing. The measured track lengths are presented in histograms where $n_{i}$ is the number of tracks with length reduction given by $\mathrm{r}_{\mathrm{i}}=\mathrm{L}_{\mathrm{i}} / \mathrm{L}_{0}(\mathrm{i}=1,2$, .), where $\mathrm{L}_{0}$ and $\mathrm{L}_{\mathrm{i}}$ are the track lengths with and without annealing, respectively. By applying the Length bias correction the $n_{i}$ values are corrected into new values, $n_{i}$, which are obtained from a factor $F\left(r_{i}\right)$ involving the probability that the tracks will be observed after the chemical etching. The corrected histograms are obtained through:

where:

$$
\begin{gathered}
r_{i}=r_{j} \\
n_{j}=N \cdot F\left(r_{i}\right) \\
N=\sum_{i} n_{i} \\
F\left(r_{i}\right)=\frac{n_{i} r_{i}^{-1}}{\sum_{i} n_{i} r_{i}^{-1}}
\end{gathered}
$$

ii) Obtainment of $r_{s}$ (corr): As consequence of the track length shortening, the density $\left(r_{S}\right)$ is reduced. In such case a corrected $r_{S}$ can be obtained plotting the density reduction $\left(\mathrm{r}_{\mathrm{S}} / \mathrm{r}_{0}\right)$ in function of the length reduction $\left(\mathrm{L} / \mathrm{L}_{0}\right)$. To carry out this correction we used the following data (Green, 1988):

$$
\mathrm{d}_{\mathrm{j}}=\mathrm{dj} \text {; for } \mathrm{r}_{\mathrm{j}}>1.0
$$$$
\mathrm{d}_{\mathrm{j}}=-0.0895+1.0895 \mathrm{r}_{;} \text {; for } 0.7<\mathrm{r}_{j} £ 1.0
$$$$
\mathrm{d}_{\mathrm{j}}=-0.0890+2.2341 \mathrm{r}_{j} \text {; for } 0.4<\mathrm{r}_{\mathrm{j}} £ 0.7
$$$$
\mathrm{d}_{\mathrm{j}}=0 \text {; for } \mathrm{r}_{\mathrm{j}} £ 0.4
$$

where:

$$
\mathrm{d}_{\mathrm{i}}=\rho_{\mathrm{j}} / \rho_{0} .
$$

In this way $\mathrm{r}_{\mathrm{S}}$ (corr) is given by:

$$
\begin{array}{r}
\rho_{S}(\text { corr })=\frac{\rho_{S}}{C} \\
C=\frac{\sum_{j} n_{j} \cdot d_{j}}{N}
\end{array}
$$

The error of $\mathrm{C}$ was found by error propagation. 